Review

\title{
POPULATION GENETICS OF LATVIANS IN THE CONTEXT OF ADMIXTURE BETWEEN NORTH-EASTERN EUROPEAN ETHNIC GROUPS
}

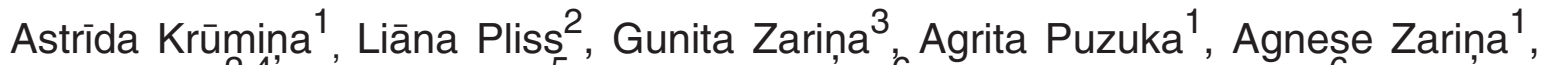 \\ Baiba Lāce ${ }^{2,4^{\prime}}$, Didzis Elferts ${ }^{5}$, Andrey Khrunin ${ }^{6}$, Svetlana Limborska ${ }^{6}$, \\ Jānis Kloviṇš ${ }^{2}$, and Linda Gailìte (Piekuse) $)^{1, \#}$ \\ ${ }^{1}$ Scientific Laboratory of Molecular Genetics, Rīga Stradiṇš University, Rīga, 16 Dzirciema Str., LV-1007, LATVIA \\ ${ }^{2}$ Latvian Biomedical Research and Study Centre, 1 Rātsupītes Str., LV-1067, Rīga, LATVIA \\ ${ }^{3}$ Institute of Latvian History, University of Latvia, 4 Kalpaka Blvd., Rīga, LV-1050, LATVIA \\ ${ }^{4}$ Centre Hospitalier De I'Université Laval, 2705 Boulevard Laurier, Ville de Québec, QC G1V 4G2, Québec, CANADA \\ ${ }^{5}$ Faculty of Biology, University of Latvia, 1 Jelgavas Str., LV-1004, Rīga, LATVIA \\ ${ }^{6}$ Institute of Molecular Genetics, Russian Academy of Sciences, 2 Kurchatov Sq., Moscow, 123182, RUSSIA \\ \# Corresponding author, linda.gailite@ rsu.Iv
}

Contributed by Jānis Kloviṇš

This article presents a review on population genetics of Latvians, which alongside Lithuanians are the two extant Baltic speaking populations. The article provides a description of genome-wide single nucleotide polymorphism (SNP) data and contains a comparative analysis of the results of studies performed on classical autosomal genetic markers, mitochondrial DNA (mtDNA) and the non-recombining part of the $Y$ chromosome (NRY), with data on neighbouring populations. The study also covers data of recently performed ancient DNA (aDNA) studies carried out on samples from the territory of today's Latvia. The results of population genetic studies have shown a mixture of eastern and western genetic traits in present-day Latvians with only small differences between Latvian subpopulations. Studies of the Baltic "tribal gene" $L W^{b}$, as well as the gene's SERPINA1 allele PIZ have indicated the presence of a considerable Baltic admixture in the neighbouring Finno-Ugric and Slavic populations. Although mtDNA analyses have shown that Latvians genetically in general belong to the same common gene pool as most of the Europeans, the $Y$-chromosomal lineage composition suggests that they are most similar to Northern and Eastern European populations of Lithuanians, Estonians, and Eastern-Slavic populations, which are ethnogenetically closest to them. The analysis of aDNA from the Early and Middle Neolithic did not present any genomic evidence of gene-flow from Central European farmers or any mitochondrial or Y-chromosomal haplogroups that are typical for them in the hunter-gatherers from the territory of today's Latvia and Lithuania.

Key words: population genetics, Latvians, autosomes, mitochondrial DNA, Y chromosome.

\section{INTRODUCTION}

Contemporary people of North-Eastern European populations, including Latvians, genetically are very similar to the neighbouring populations. Principal component (PC) analysis of more than 270000 autosomal SNPs in 3112 individuals from general populations across 16 European countries resulted in the development of genetic maps with four clusters displaying the Baltic region (Estonia, Latvia, and Lithuania) in the same cluster with Western Russia and Poland (Nelis et al., 2009; see below for details). However, there are several issues concerning Latvian ethnogenesis that remain unanswered, such as: differentiation of regional subpopulations, paternal and maternal population history, migrations affecting the region from external and internal population events, genetic admixture with neighbouring populations and identification of genetic markers that can distinguish Finno-Ugric, Slavic and Baltic influences in the Baltic Sea region.

\section{HISTORICAL BACKGROUND}

The early inhabitants of the Eastern Baltic region were reindeer hunters who arrived to this territory after the retreat of 
the continental ice sheet $\sim 12000$ years before present (YBP, all data calibrated), at the end of the Last Glacial period (Gimbutiene, 1994; Zagorska, 2012; Bērziňš and Vasks, 2013). The present-day territory of Latvia evidently represented the northernmost limit of the distribution of these hunter groups on the eastern shore of the Baltic Basin. All findings indicate that reindeer hunters reached the area of present-day Latvia from southern periglacial refuges in the course of repeated seasonal migrations. Their groups were small and mobile (Zagorska, 2012). As climatic conditions improved 7500-10 000 YBP, the first stable settlements in the Eastern Baltic region appeared (Gimbutiene, 1994; Radiňš, 2012; Bērziņš and Vasks, 2013). The most ancient settlements in southern Lithuania are some 2000 years older than the first settlements in Latvia and Estonia (Rimantiene, 1996). The Neolithic transition in North-Eastern Europe is thought to have been slower and more gradual than in Western/Central Europe and to have involved little if any migration of early farmers from Central Europe (Jones et al., 2017; Mathieson et al., 2017; Mittnik et al., 2017a). There is a suggestion that the Eastern Baltic was a genetic refugium for hunter-gatherer populations during the Neolithic period (Malmström et al., 2009; Lazaridis et al., 2014; Mittnik et al., 2017a). The persistence of hunter-gatherer ancestry in the Baltic region until at least the Middle Neolithic provides a possible source for the resurgence of hunter-gatherer ancestry in Central Europe from 7000 to 5000 YBP (Haak et al., 2015). From the Neolithic onwards, archaeological and historical records reveal contacts between populations of North-Eastern Europe and other groups. Finno-Ugric tribes arrived to the Baltic region from the East/South East 6000-5000 YBP (Sedovs, 2004). These tribes are regarded to be the ancestors of modern Estonians. The next migration wave came from the South $\sim 1000$ years later. These were steppe pastoralists South-Eastern European populations who spoke the Indo-European language - Proto-Balts who are considered as the predecessors of ancient Prussians, Yotvingians, as well as the present-day Latvians and Lithuanians (Česnys, 1991; Sedovs, 2004; Radiņ̌s, 2012). There is a near-consensus among linguists that the Baltic and Slavic languages stem from a common root, Proto-Balto-Slavic, which separated from other Indo-European languages 4500-7000 YBP (Bouckaert et al., 2012, Haak et al., 2015). The split between Baltic and Slavic branches has been dated to around 3500-2500 YBP (Gray and Atkinson, 2003; Novotna and Blažek, 2007; Bouckaert et al., 2012). Proto-Balts pushed the Finno-Ugric populations up north, and in the territory of the present-day Latvia and Lithuania the Finno-Ugric and other ethnic groups were assimilated into the Indo-European-speaking main Baltic population. The major Finno-Ugric tribes that have inhabited the Baltic region are the Finns, the Estonians and the presently almost completely assimilated Livs, who previously settled around the Gulf of Riga, i.e. in present-day south-western Estonia and north-western Latvia. The expansion of the Baltic tribes northwards and eastwards marked the beginning of contacts between Baltic and Finno-Ugric populations and their languages. The contact zone was impressive — starting from

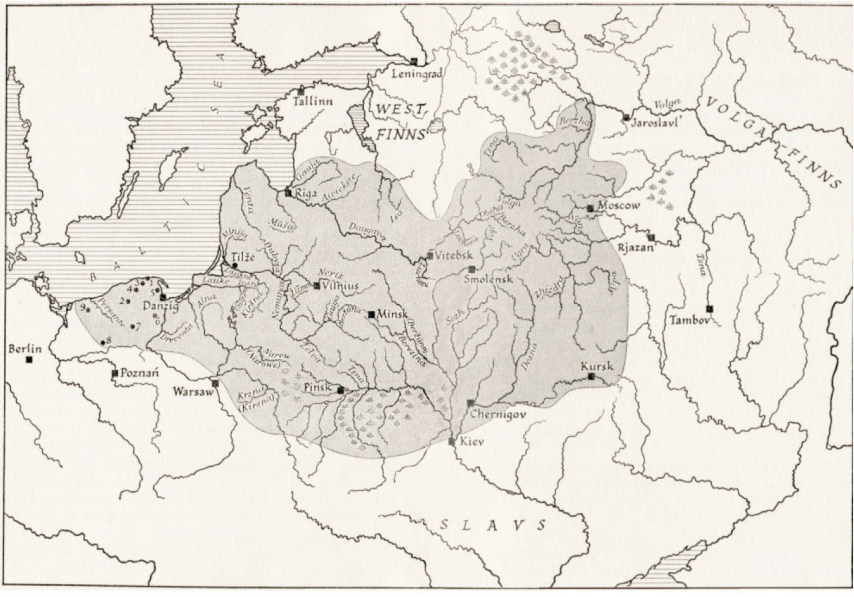

Fig. 1. The map of the territory with Baltic hydronyms (Gimbutiene, 1994).

the Baltic Sea in the West to the upper reaches of the Oka and Volga rivers in the east — see the map of Baltic hydronyms (names of rivers, lakes and other bodies of water given in Fig. 1). The eastern stem of the Balts, who did not succeed to survive till historical times, had linguistic contacts with the tribes of Mari and Mordvins (Mordvi). The influence of the Baltic languages on Finnish is evident. For instance, there are about $1.1 \%$ of Balticisms in modern Finnish (Hakulinen, 1961). The differentiation of the Baltic tribes was completed around 2000-1500 YBP. According to the available data, around 2500 YBP Finno-Ugric tribes still inhabited the northern Curonian lands up to the river Abava, the Riga shore and practically the entire territory of Latvia northwards from the Daugava River. Curonian, Semigalian, Selonian, and Latgalian tribes and languages began to merge in the southernmost areas. The fusion of these tribes gave rise to the Latvian nation (Vasks et al., 1997). The Lithuanian nation was formed south of Latvia (Kučinskas, 2001). In the middle of the $1^{\text {st }}$ millennium AD, Slavic tribes, representing another group of Indo-European language speakers, arrived to the Baltic territory coming along the Dnieper, Desna, and other rivers (Sedovs, 2004). The ancient Baltic territory was split into the western and eastern parts, the former comprising Old Prussian, Latvian, and Lithuanian lands, and the latter — the remaining Baltic tribes. The eastern Balts were eventually assimilated by Slavs; however, the degree of assimilation differed from region to region (Fig. 2). Thus, the contemporary population of Latvia, the focus of this review, is composed of a complex mixture of former Baltic tribes, with varying influences from Finno-Ugric and Slavic sources. Mostly due to the strategic location, since medieval times the territory of Latvia was a frequent focal point for conquests among Germany, Poland, Sweden, and Russia.

The Baltic Sea has been a considerable geographical hurdle to human migration in prehistoric times when changes in the genetic constitution due to migration were most profound. This is reflected by the differences between populations on the western (Swedish) and eastern (Finnish and Baltic) side of the Baltic Sea with respect to cultural, lin- 


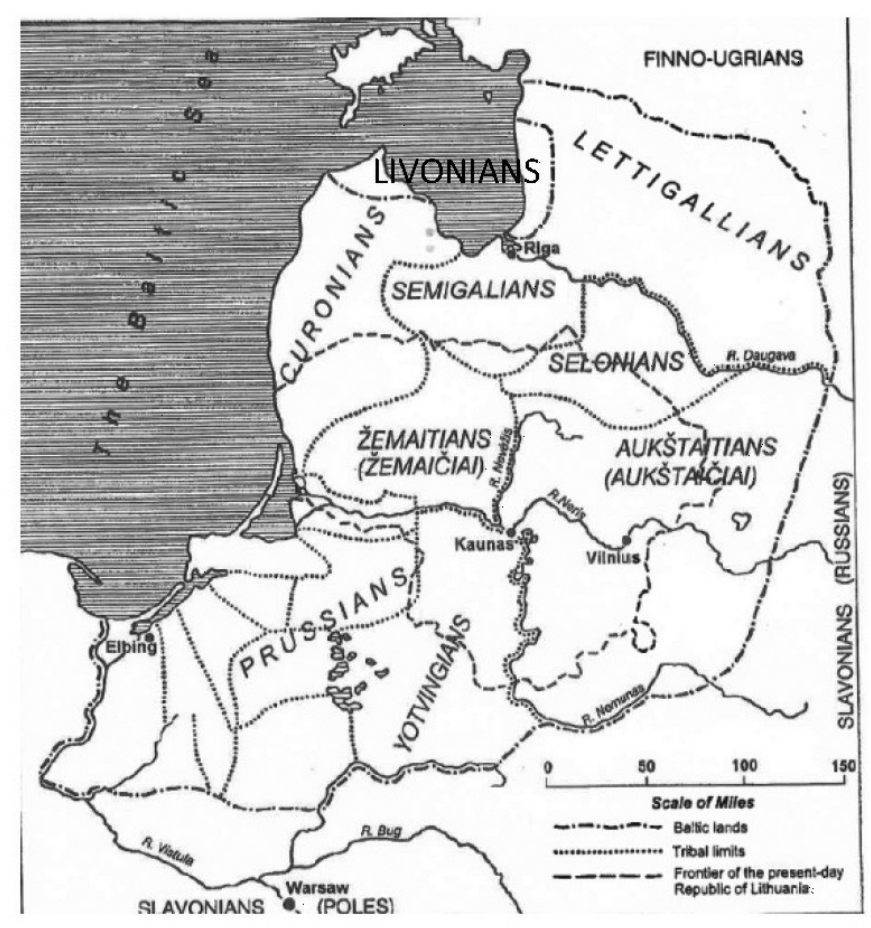

Fig. 2. Baltic tribes in the 13th century. Adapted from Gimbutiene (1994) and Kučinskas (2001).

guistic and genetic characteristics. The original populations on the eastern side of the Baltic Sea speak Finno-Ugric or Baltic languages, whereas those on the western side speak Germanic languages. Although the Baltic Sea has been a geographical barrier to human migration in the past, archaeological and historical evidence indicate that particularly from about $500 \mathrm{AD}$ there have been lively contacts between the peoples of the Baltic Sea region.

$3 \mathrm{~A}$

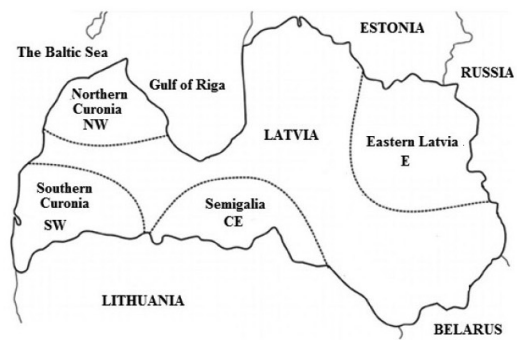

3B

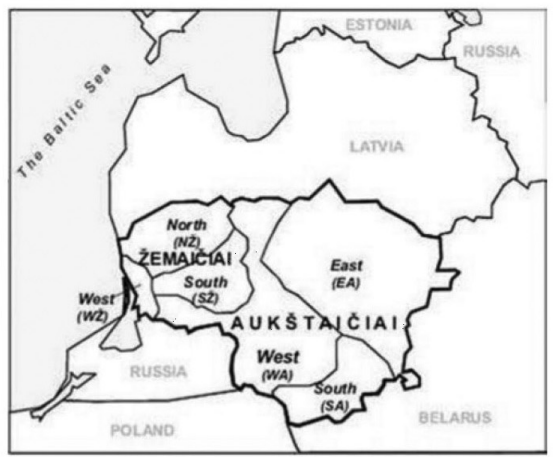

\section{GENETIC STUDIES OF LATVIANS}

Genetic studies of Latvians were started in the first decades of the $20^{\text {th }}$ century with exploration of blood groups and different anthropological features. A high frequency of blood group B (marking eastern influence) combined with high frequency of Rh-negative blood group (West European trait) was found (Prīmanis, 1937; Cauna, 1942). Contemporary molecular genetic investigations of the Latvian population were begun only 20 years ago. Over the last decade, the ability to investigate population genetic structure has been significantly enhanced by advances in high-throughput genotyping technologies, as they allow simultaneous genotyping of hundreds of thousands of polymorphic markers.

This review deals mainly with the results obtained on unrelated healthy ethnic Latvians representing anthropologically, archaeologically, and ethno-linguistically four different regions of Latvia: Northern Courland (Lat. Curonia) (North-Western region, NW), Southern Courland (SouthWestern region, SW), Semigalia (Central region, CE) and Vidzeme/Latgalia (Lat. Lettgallia) (Eastern region, E) (Denisova, 1975; Denisova, 1997, Fig. 3A), who have been inhabitants of each of these regions for at least three generations.

Results of studies performed on autosomal genetic markers (genome-wide single nucleotide polymorphisms and classical autosomal genetic markers), mitochondrial DNA (mtDNA) and the non-recombining part of the Y chromosome (NRY) will be considered and compared with the data from neighbouring populations (Fig. 3B). Data on populations from some Western and Southern European countries are included mainly for comparison. The uniparentally in-

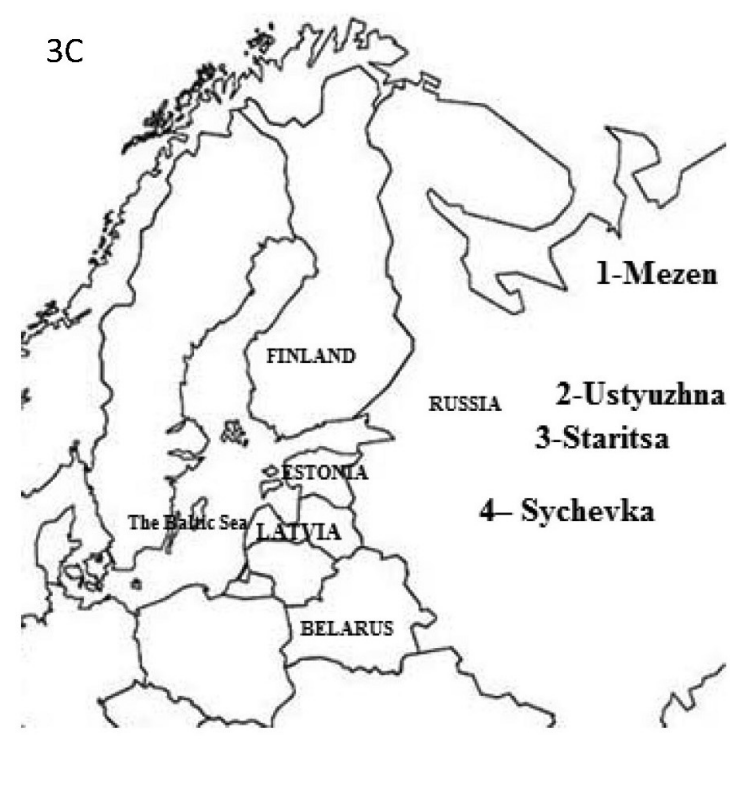

Fig. 3. Geographic location of Latvian and neighbouring subpopulations used in the reviewed population genetic studies. 3A, Latvian subpopulations: NW, North-Western region (Northern Curonia (Courland)). Ancient territory of Livonians; CE, Central region (Semigalia). Ancient territory of Semigalians; SW, South-Western region (Southern Curonia (Courland)). Ancient territory of Curonians; E, Eastern region (Vidzeme /Latgalia). Ancient territory of Latgalians; 3B, Lithuanian subpopulations (Kučinskas, 2001); 3C, Russian subpopulations: 1, Mezen district (Archangelsk Oblast); 2, Ustyuzhna district (Vologda Oblast); 3, Staritsa district (Tver Oblast); 4, Sychevka district (Smolensk Oblast). 
herited mtDNA and NRY are two loci that have been extensively studied in human populations, in part because they represent maternal and paternal population histories and in part because they do not undergo recombination and, therefore, lineages can be more easily traced back to a single common ancestor. There are differences in the action of genetic drift and natural selection on mtDNA and NRY loci as compared to autosomal loci. Thus, a combination of mtDNA and NRY loci with autosomal data is necessary for a thorough understanding of population history.

Results of studies on ancient DNA samples are also included because analysis of ancient DNA can provide information on past population histories that is not retrievable from contemporary individuals.

In this review, besides a description of genome-wide SNP data, we will also focus on several autosomal genes. These genes are chosen because of known regional frequency differences in North-Eastern Europe. They give information not only on the history of certain mutations, but also on population migration routes in Eastern Baltic, possible selective advantages of these mutations and their contribution to diseases. For two autosomal diseases (cystic fibrosis and phenylketonuria), phenotype (not allelic) frequencies have been compared. Frequencies of the mentioned diseases are given for the general (not ethnic) population.

\section{AUTOSOMAL GENETIC MARKERS}

Genome-wide single nucleotide polymorphisms (SNPs). The ability to investigate population genetic structure has been significantly improved over the last decade by advances in high-throughput genotyping technologies. Genome-wide analyses in human populations allow to unveil the demographic history underlying the genetic patterns of diversity observable today across the globe. In Europe the strongest genetic differentiation has been found between the north-west and south-east parts of the continent (Li et al., 2008). Populations from North-Eastern Europe, incl. Latvians, are less represented in these studies.

As already mentioned at the beginning of the introductory part, principal component (PC) analysis (PCA) of more than 270000 autosomal SNPs genotyped with the Illumina Infinium platform in 3112 individuals from general (but not always ethnic) populations across 16 European countries, including 95 individuals from Latvia, resulted in a boomerang-like structured genetic map of Europe with four clusters displaying individuals from the Baltic region (Latvia, Lithuania, and Estonia) in the same cluster with Polish and western Russian samples (Fig. 4; Nelis et al., 2009).

Khrunin et al. (2013) examined the European population structure with 166000 autosomal SNPs and obtained another genetic map of Europe (some populations from NorthEastern regions of the European part of Russia, Komi, Veps, Northern Russians were also included in the study). In the space of the plotted first two principal components,

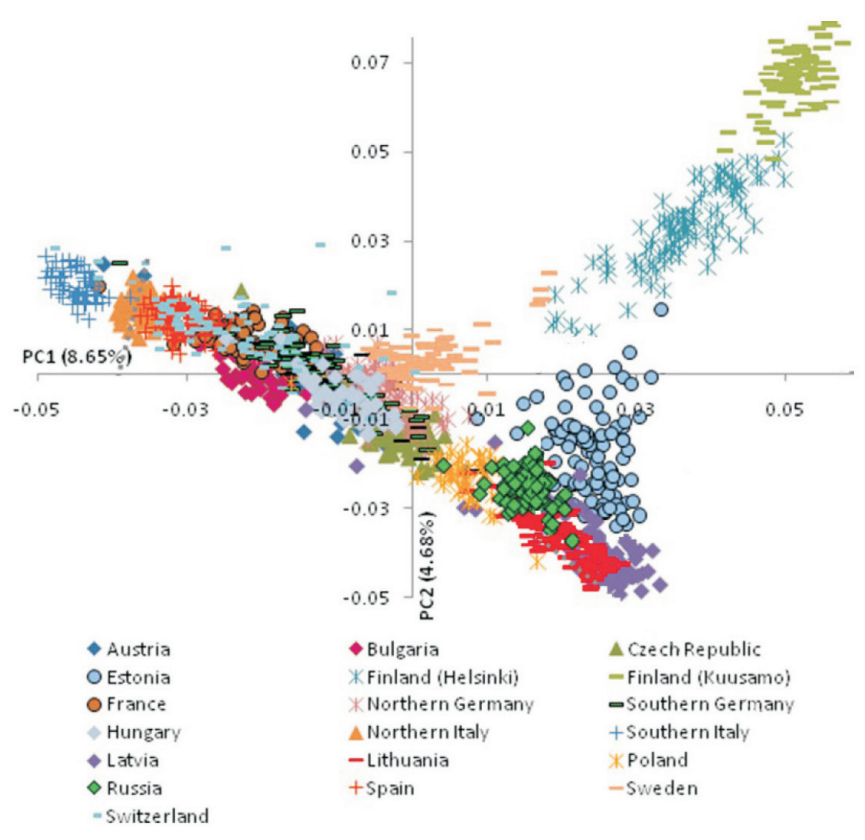

Fig. 4. The European genetic structure (based on 273464 SNPs) as revealed by Principal Component Analysis (Nelis et al., 2009).

Latvians clustered in close proximity to populations from Central and Eastern Europe, demonstrating the highest similarity with autosomal SNP profiles of Russians from the central part of European Russia and Estonians (Lithuanians were not included in the study). The relationships found were similar with the results of ADMIXTURE ancestry analysis, revealing a particular specificity of the Latvian gene pool, which exhibited a lower proportion of the "Finnic" ancestry component than in Estonians. Additionally, Latvians had the highest proportion of non-specified yellow component (there were no populations in the data set that had only this component in their genomes), which was omnipresent throughout the studied European populations (Khrunin et al., 2013).

Similar results of the genetic analysis of Balto-Slavic speaking populations were obtained by Kushniarevich et al. (2015), who demonstrated the proximity of autosomal genome-wide SNP profiles of Latvians (six individuals analysed) and Lithuanians to East Slavs and Estonians. The results showed that Latvians and Lithuanians shared higher number of segments that were identical by descent with the combined group of east-west Slavs than in other non-Slavic people did (Kushniarevich et al., 2015).

Results on high-coverage whole-genome sequence studies performed on three present-day Latvians are included in the dataset of Estonian Biocentre Human Genome Diversity Panel (Pagani et al., 2016). The dataset was analysed for numerous parameters, including shared ancestry, archaic admixture, and changes in effective population size through time. These analyses have shown that Latvians are located in the North European genetic cluster with highest similarity to Lithuanians. 


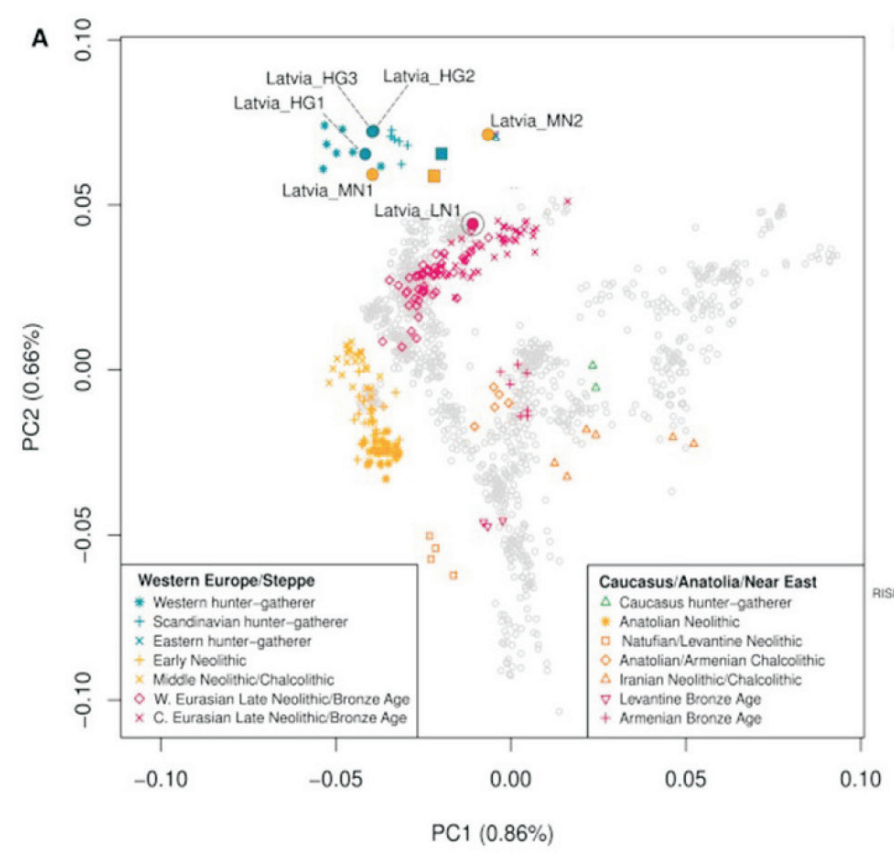

As it was already mentioned in the Introduction, information on past population histories can be provided by genomes obtained from ancient biological remains. Recently performed genome-wide ancient DNA (aDNA) studies have revealed a complex population history of modern Europeans involving at least three major prehistoric migrations (Lazaridis et al., 2014; Allentoft et al., 2015; Haak et al., 2015; Saag et al., 2017). While these events are relatively well described in Central and Southern Europe, their genetic impact on North-Eastern Europe is not so extensively studied.

Data of recently performed genome-wide analyses of 30 Latvian ancient DNA samples are presented in Table 1. PCA comparison of 15 Latvian Mesolithic and Early Neolithic samples with data of ancient Western European hunter-gatherers (WHG) and Eastern European huntergatherers (EHG) as well with the genomic data of modern Europeans showed clustering of ancient Latvian samples between WHG and EHG (with closer affinity to WHG than to EHG) as well as their location close to modern Northern and Eastern European populations (Jones et al., 2017; Mathieson et al., 2017; Fig. 5). These data allow to suggest some genetic continuity in this region since the Mesolithic period. Similar results were obtained also for ancient Lithuanian samples (Mathieson et al., 2017; Mittnik et al., 2017a). Remarkable changes in the genetic data are observed in the samples from the period between the Early Neolithic and the Middle Neolithic, when clear influence from exogenous Northern Eurasian populations is observed (Jones et al., 2017; Mathieson et al., 2017), and also, Late Neolithic and Bronze Age samples show impact from the Pontic Steppe populations (steppe pastoralists). There are no signs of Anatolian farmer-related genetic input on populations of Latvia and Lithuania at least until the end of the Bronze Age (Jones et al., 2017; Mathieson et al., 2017; Mittnik et al., 2017a). Remarkably, the Steppe-related genetic impact coincides with the proposed emergence of
B

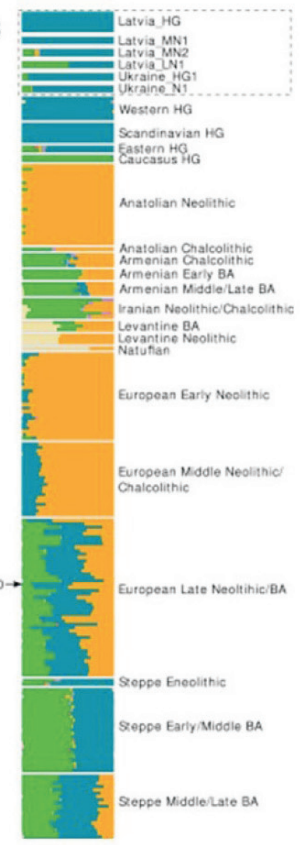

Fig. 5. Principal component analysis (PCA) and ADMIXTURE analysis of ancient Latvian DNA samples (adapted from Jones et al., 2017). 5A, ancient DNA data presented in the study as well as published ancient DNA data are projected onto the first two principal components defined by selected modern Eurasian data; 5B, ADMIXTURE ancestry components for ancient DNA samples showing that the Latvian Neolithic samples do not have the yellow component that dominates in Anatolian and early European farmers. The Latvian and Ukrainian samples presented in the study are displayed in a gray box and at twice the height of the other ancient samples for ease of visualization. The arrow shows an Estonian Bronze Age sample (RISE00) (Allentoff et al., 2015) that has a yellow component. MN, Middle Neolithic; LN, Late Neolithic; N, Neolithic; HG, hunter-gatherer; BA, Bronze Age; W, Western; C, Central.

Indo-European languages in the Baltic region (Bouckaert et al., 2012; Haak et al., 2015).

Genome-wide analysis of polymorphisms presents a general conception about relationships and evolutionary trajectories of population formation. In addition, population analysis of local genomic regions may provide information about historical traces of particular lineages within populations.

Gene $\boldsymbol{C F T R}$, allele $\triangle$ F508. Gene $C F T R(\mathrm{OMIM} * 602421)$ encodes protein CFTR - cystic fibrosis transmembrane conductance regulator, which acts as a chloride ion channel. Mutations in the gene cause cystic fibrosis (CF; OMIM \#219700), one of the most common severe autosomal recessive disorders in populations of Northern European ancestry in most countries, affecting 1 in 2000 to 4000 individuals (Table 2). Gene mutations affect the salt and water balance of the mucus layer lining epithelial surfaces mostly in the lungs and pancreas. The major cystic fibrosis mutation is $\Delta$ F508 (delta-F508) deletion of three base pairs at codon 508 , which results in a loss of the amino acid phenylalanine in the protein. The incidence of $\Delta \mathrm{F} 508$ carriers among healthy Latvians is $1: 42$, which corresponds to the frequency of $\Delta F 508$ mutation carriers in most North European populations (Krumina et al., 2001b). This mutation was found in $61.3 \%$ of chromosomes in the overall $\mathrm{CF}$ patient population in Latvia. The incidence of $\mathrm{CF}$ as well as of $\Delta$ F508 varies markedly among different populations. There is a north-west/south-east gradient in the incidence of $\mathrm{CF}$ throughout Europe, with the highest incidence found in Ireland and England (1/1353 and 1/2381; Farrell, 2008), and the lowest in Finland (1/25 000; Farrell, 2008). To trace the history of $\Delta F 508$ in Latvia the association of $\Delta F 508$ with five polymorphic DNA markers was studied. The haplotypes observed on $\triangle \mathrm{F} 508 \mathrm{CF}$ chromosomes were the same as in other populations. Distribution of haplotypes found in the Latvian population, together with frequencies of $\Delta \mathrm{F} 508$ mutation, is intermediate between Northern- and South- 
RESULTS OF GENOME ANALYSIS FROM ANCIENT LATVIAN DNA SAMPLES

\begin{tabular}{|c|c|c|c|c|c|c|c|}
\hline Sample's code & Cemetery/burial $^{6}$ & $\begin{array}{c}\text { Sample's age } \\
\text { (cal YBP)* }\end{array}$ & Cultural attribution & $\begin{array}{c}\text { Mean genome } \\
\text { coverage }\end{array}$ & $\begin{array}{c}\text { Gene's } \\
M C M 6 \\
\text { ancestral } \\
\text { allele } \\
\end{array}$ & $\begin{array}{c}\text { mtDNA } \\
\text { haplogroup }\end{array}$ & NRY haplogroup \\
\hline Zvej $30^{2}$ & Zvejnieki 305 & $8240 \pm 70$ & $\begin{array}{c}\text { Mesolithic } \\
\text { hunter-gatherers }\end{array}$ & 2.43 & nda & $\mathrm{U} 5 \mathrm{a} 2 \mathrm{c}$ & R1b1a1a \\
\hline Latvia HG1 ${ }^{1}$, Zvej32 ${ }^{2}$ & Zvejnieki 313 & $7525 \pm 60$ & $\begin{array}{c}\text { Mesolithic } \\
\text { hunter-gatherers }\end{array}$ & $1.38^{1}, 3.51^{2}$ & $++^{4}$ & $\mathrm{U}^{\mathrm{a}} 1 \mathrm{c}^{1}{ }^{12}$ & Female \\
\hline Zvej $10^{2}$ & Zvejnieki 67 & $7140 \pm 40$ & $\begin{array}{c}\text { Mesolithic } \\
\text { hunter-gatherers }\end{array}$ & 3.76 & nda & U5a2c & R1b1a1a \\
\hline Latvia HG2 ${ }^{1}, Z_{v e j} 25^{2}$ & Zvejnieki 93 & $6840 \pm 55$ & $\begin{array}{c}\text { Mesolithic } \\
\text { hunter-gatherers }\end{array}$ & $4.37^{1}, 0.54^{2}$ & $++^{4}$ & $\mathrm{U} 2 \mathrm{e} 1^{1},{ }^{2}$ & $\mathrm{R} 1 \mathrm{~b} 1 \mathrm{~b}^{1}, \mathrm{R} 1 \mathrm{~b} 1 \mathrm{a} 1 \mathrm{a}^{2}$ \\
\hline Zvej20 2 & Zvejnieki 86 & $6815 \pm 40$ & $\begin{array}{c}\text { Mesolithic } \\
\text { hunter-gatherers }\end{array}$ & 3.78 & nda & U5b1d1 & R1b1a1a \\
\hline${\text { Zvej} 12^{2}}^{2}$ & Zvejnieki 128 & $6530 \pm 35$ & $\begin{array}{c}\text { Mesolithic } \\
\text { hunter-gatherers }\end{array}$ & 3.48 & nda & U5a2d & R1b1a1a \\
\hline Zvej3 $3^{2}$ & Zvejnieki 52 & Not dated & $\begin{array}{c}\text { Mesolithic } \\
\text { hunter-gatherers }\end{array}$ & 4.42 & nda & U5b2a1a & Q1a2 \\
\hline Zvej4 $4^{2}$ & Zvejnieki 108 & Not dated & $\begin{array}{c}\text { Mesolithic } \\
\text { hunter-gatherers }\end{array}$ & 3.90 & nda & $\mathrm{U} 5 \mathrm{a} 2 \mathrm{c} 3$ & I2a2a1 \\
\hline Zvej5 $5^{2}$ & Zvejnieki 117 & Not dated & $\begin{array}{c}\text { Mesolithic } \\
\text { hunter-gatherers }\end{array}$ & 4.17 & nda & U5a1d & Female \\
\hline $\mathrm{Zvej}^{2}$ & Zvejnieki 98 & Not dated & $\begin{array}{c}\text { Mesolithic } \\
\text { hunter-gatherers }\end{array}$ & 1.03 & nda & U5a1c & $\mathrm{I} 2 \mathrm{a} 2 \mathrm{a} 1$ \\
\hline Zvej16 ${ }^{2}$ & Zvejnieki 224 & $6335 \pm 35$ & $\begin{array}{l}\text { Mesolithic/Neolithic } \\
\text { hunter-gatherers }\end{array}$ & 3.82 & nda & $\mathrm{U} 4 \mathrm{~b} 1 \mathrm{a} 2$ & I2a1 \\
\hline Zvej $21^{2}$ & Zvejnieki 197 & $6180 \pm 30$ & $\begin{array}{l}\text { Mesolithic/Neolithic } \\
\text { hunter-gatherers }\end{array}$ & 3.22 & nda & U4a1 & I2a1 \\
\hline Latvia HG3 ${ }^{1}, Z^{2}$ ej2 $27^{2}$ & Zvejnieki 121 & $6145 \pm 55$ & $\begin{array}{l}\text { Mesolithic/Neolithic } \\
\text { hunter-gatherers }\end{array}$ & $0.97^{1}, 2.88^{2}$ & $+-{ }^{4}$ & U5a2d & $\mathrm{R} 1 \mathrm{~b} 1 \mathrm{~b}^{1}, \mathrm{R} 1 \mathrm{~b} 1 \mathrm{a} 1 \mathrm{a}^{2}$ \\
\hline Zvej $22^{2}$ & Zvejnieki 173 & $5900 \pm 30$ & $\begin{array}{l}\text { Early Neolithic } \\
\text { hunter-gatherers }\end{array}$ & 3.52 & nda & U5a1c & $\mathrm{I} 2 \mathrm{a} 2 \mathrm{a} 1 \mathrm{~b}$ \\
\hline Zvej $15^{2}$ & Zvejnieki 226 & $5370 \pm 30$ & $\begin{array}{l}\text { Early Neolithic } \\
\text { hunter-gatherers }\end{array}$ & 3.60 & nda & U5a1d2 & Female \\
\hline Zvej14 ${ }^{2}$ & Zvejnieki 261 & $5335 \pm 30$ & $\begin{array}{l}\text { Middle Neolithic } \\
\text { hunter-gatherers }\end{array}$ & 3.30 & nda & U4a1 & R1bla1a \\
\hline Latvia MN1 ${ }^{1}$, Zvej26 ${ }^{2}$ & Zvejnieki 124 & $5280 \pm 55$ & $\begin{array}{l}\text { Middle Neolithic } \\
\text { hunter-gatherers }\end{array}$ & $0.18^{1}, 1.77^{2}$ & nda & U4a1 & nda $^{1}$, R1b1a1a ${ }^{2}$ \\
\hline Zvej13 ${ }^{2}$ & Zvejnieki 278 & $5210 \pm 30$ & $\begin{array}{l}\text { Middle Neolithic } \\
\text { hunter-gatherers }\end{array}$ & 3.41 & nda & U4a1 & Female \\
\hline Latvia MN2 $^{1}$ & Zvejnieki 221 & $5180 \pm 65$ & $\begin{array}{c}\text { Middle Neolithic. Comb } \\
\text { Ware culture }\end{array}$ & 1.50 & $++{ }^{4}$ & $\mathrm{U} 4$ & Female \\
\hline Zvej2 $24^{2}$ & Zvejnieki 207 & $5180 \pm 30$ & $\begin{array}{l}\text { Middle Neolithic } \\
\text { hunter-gatherers }\end{array}$ & 2.53 & nda & U4a1 & Female \\
\hline Latvia $\mathrm{LN}^{1}$, Zvej $28^{2}$ & Zvejnieki 137 & $4280 \pm 60$ & $\begin{array}{l}\text { Late Neolithic. Corded } \\
\text { Ware culture }\end{array}$ & $0.26^{1}, 0.32^{2}$ & nda & $\mathrm{U} 5 \mathrm{a} 1^{1}, \mathrm{U} 5 \mathrm{a} 1 \mathrm{~b}^{2}$ & Female \\
\hline Kivutkalns $42^{3}$ & Kivutkalns 42 & $2573 \pm 30$ & Late Bronze Age & 1.10 & $+-^{5}$ & H1b1 & Female \\
\hline Kivutkalns $25^{3}$ & Kivutkalns 25 & $2545 \pm 30$ & Late Bronze Age & 1.57 & $--^{5}$ & $\mathrm{H} 28 \mathrm{a}$ & R1a1a1b \\
\hline Kivutkalns $153^{7}$ & Kivutkalns 153 & $2542 \pm 29$ & Late Bronze Age & 0.33 & ++ & U5a1a1 & R1b1a2 \\
\hline Kivutkalns $207^{3}$ & Kivutkalns 207 & $2511 \pm 30$ & Late Bronze Age & 7.21 & $+-^{5}$ & $\mathrm{H} 1 \mathrm{~b} 2$ & Female \\
\hline Kivutkalns $209^{3}$ & Kivutkalns 209 & $2497 \pm 30$ & Late Bronze Age & 2.24 & $+-^{5}$ & J1b1a1 & R1a1a \\
\hline Kivutkalns $215^{3}$ & Kivutkalns 215 & $2462 \pm 27$ & Late Bronze Age & 2.74 & $+-^{5}$ & $\mathrm{H} 1 \mathrm{c}$ & Female \\
\hline Kivutkalns $222^{3}$ & Kivutkalns 222 & $2423 \pm 26$ & Late Bronze Age & 1.28 & $+-^{5}$ & U5a1c1 & R1a1 \\
\hline Kivutkalns $19^{3}$ & Kivutkalns 19 & $2403 \pm 24$ & Late Bronze Age & 5.76 & $++^{5}$ & H10a & R1a1a1b \\
\hline Kivutkalns $194^{3}$ & Kivutkalns 194 & $2298 \pm 28$ & Late Bronze Age & 0.15 & $--^{5}$ & T1a1b & R1a1a \\
\hline
\end{tabular}

Notes: *al YBP, calibrated years before present; nda, no data available; ${ }^{1}$ Jones et al., 2017; ${ }^{2}$ Mathieson et al., 2017; ${ }^{3}$ Mittnik et al., $2017 \mathrm{a}$; Jones et al., 2017; ${ }^{4}$ ancestral allele 22018G (rs182549) (Mittnik et al., 2017b); ${ }^{5}$ ancestral allele 13910C (rs4988235); ${ }^{6}$ Zarina's data; ${ }^{7}$ Mittnik et al., $2017 \mathrm{~b}$. 
INCIDENCE OF CYSTIC FIBROSIS AND PHENYLKETONURIA IN EUROPEAN POPULATIONS

\begin{tabular}{l|c|c|c|c}
\hline \multicolumn{1}{|c|}{ Populations } & $\begin{array}{c}\text { Phenyl- } \\
\text { ketonuria } \\
\text { (PKU) }\end{array}$ & $\begin{array}{c}\text { R408W } \\
\text { (rs5030858) } \\
\text { frequency (\%) } \\
\text { of PKU alleles }\end{array}$ & $\begin{array}{c}\text { Cystic } \\
\text { fibrosis } \\
\text { (CF) }\end{array}$ & $\begin{array}{c}\Delta \text { F508 } \\
\text { (rs113993960) } \\
\text { frequency (\%) } \\
\text { of CF alleles }\end{array}$ \\
\hline Latvians & $1 / 8000^{1}$ & 73.0 & $1 / 3300^{4}$ & 61.3 \\
Lithuanians & $1 / 10000^{3}$ & 73.4 & $1 / 2500^{5}$ & 34.0 \\
Russians & $1 / 10000^{3}$ & 56.5 & $1 / 4900^{7}$ & 54.5 \\
Belarusians & $1 / 5600^{3}$ & 68.2 & $1 / 8000^{8}$ & 61.2 \\
Ukrainians & $1 / 8300^{3}$ & 57.0 & $1 / 3300^{5}$ & 65.2 \\
Poles & $1 / 8000^{3}$ & 62.2 & $1 / 5000^{5}$ & 57.1 \\
Czechs & $1 / 7000^{2}$ & 61.1 & $1 / 2833^{5}$ & 70.0 \\
Danes & $1 / 12000^{2}$ & 18.2 & $1 / 4700^{5}$ & 87.5 \\
Norwegians & $1 / 14500^{2}$ & 13.8 & $1 / 4500^{6}$ & 60.2 \\
Irish & $1 / 4500^{3}$ & 42.5 & $1 / 1353^{5}$ & 70.4 \\
Swedes & $1 / 20000^{3}$ & 21.9 & $1 / 5600^{5}$ & 66.6 \\
English people & $1 / 12000^{3}$ & 11.1 & $1 / 2381^{6}$ & 75.3 \\
Germans & $1 / 8000^{3}$ & 25.7 & $1 / 3300^{5}$ & 71.8 \\
Italians & $1 / 17000^{2}$ & 1.4 & $1 / 4238^{5}$ & 50.9 \\
French & $1 / 13500^{2}$ & 14.1 & $1 / 4700^{5}$ & 67.7 \\
Estonians & $1 / 8090^{3}$ & 84.0 & $1 / 4500^{5}$ & 51.7 \\
Finns & $1 / 150000^{3}$ & 68.0 & $1 / 25000^{5}$ & 46.2 \\
\hline
\end{tabular}

${ }^{1}$ Purina et al., 1995; ${ }^{2}$ Williams et al., 2008; ${ }^{3}$ Tighe et al., 2003;

${ }^{4}$ Krumina et al., 2000; ${ }^{5}$ Farrell, 2008; ${ }^{6}$ World Health Organization;

${ }^{7}$ Stepanova et al., 2016; ${ }^{8}$ Mosse and Mosse, 2005

ern-European populations. These results are consistent with the hypothesis of a single origin and subsequent diffusion of this major CF mutation from North-Western Europe. The estimate of the number of generations elapsed since the mutation $\Delta \mathrm{F} 508$ was first introduced in Latvians is approximately 101, or 2020 years (Krumina et al., 2001b).

Gene $\boldsymbol{P A H}$, allele R408W. Gene PAH (OMIM *612349) encodes enzyme phenylalanine hydroxylase (PAH), which catalyses hydroxylation of phenylalanine to tyrosine. Mutations in the gene cause phenylketonuria (PKU; OMIM \#261600), one of the most common inborn errors of metabolism in people of European ancestry, with a frequency of 1/8000 in Latvia (Purina et al., 1995; Pronina and Lugovska, 2011; Table 2). It is an autosomal recessive disease characterised by a progressive neurodegenerative course. Over 900 mutations causing PKU have been reported in the $P A H$ gene. There are marked differences in the spectrum of $P A H$ mutations between European countries. The most prevalent mutation $\mathrm{R} 408 \mathrm{~W}$ is found at relative allele frequencies as high as $84 \%$ in Europe. In Europe, the $\mathrm{R} 408 \mathrm{~W}$ mutation is observed on chromosomes of two major haplotype backgrounds: R408W-2.3 and R408W-1.8 (Tighe et al., 2003). R408W-2.3 exhibits a gradient of allele frequency increasing eastwards, reaching its maximum in the Balto-Slavic region. R408W-1.8 exhibits an east-to-west cline in North-Western Europe, peaking in the most westerly province of Ireland. PKU in Latvia is genetically relatively homogeneous. The most common mutation R408W
FREQUENCIES OF GENE SERPINA1 ALLELES PIZ AND PIS IN EUROPEAN POPULATIONS

\begin{tabular}{|c|c|c|c|}
\hline Populations & $\mathrm{n}$ & $\begin{array}{c}\text { SERPINA1 gene } \\
\text { allele PIZ } \\
\text { (rs28929474) }\end{array}$ & $\begin{array}{c}\text { SERPINA1 gene } \\
\text { allele PIS } \\
\text { (rs17580) }\end{array}$ \\
\hline \multicolumn{4}{|l|}{ Latvians $s^{1,2}$} \\
\hline NW & 68 & 0.04 & 0.02 \\
\hline $\mathrm{CE}$ & 68 & 0.02 & 0.04 \\
\hline SW & 69 & 0.04 & 0.05 \\
\hline $\mathrm{E}$ & 65 & 0.04 & 0.03 \\
\hline Total & 270 & 0.03 & 0.03 \\
\hline \multicolumn{4}{|l|}{ Lithuanians $^{2}$} \\
\hline Žemaitija & 418 & 0.01 & 0.02 \\
\hline Aukštaitija & 496 & 0.01 & 0.01 \\
\hline Total & 914 & 0.01 & 0.02 \\
\hline \multicolumn{4}{|l|}{ Russians $(\mathrm{NW})^{3}$} \\
\hline Staritsa, Tver Oblast & 99 & 0.02 & 0.01 \\
\hline Sychevka, Smolensk Oblast & 111 & 0.01 & 0.000 \\
\hline Ustyuzhna, Vologda Oblast & 98 & 0.03 & 0.02 \\
\hline Mezen, Archangelsk Oblast & 66 & 0.04 & 0.02 \\
\hline Total (NW) & 374 & 0.02 & $0.01^{\circ}$ \\
\hline Russians (Central) ${ }^{4}$ & 2787 & 0.01 & 0.01 \\
\hline Belarusians $^{3}$ & 98 & 0.02 & 0.02 \\
\hline Poles ${ }^{4}$ & 9539 & 0.01 & 0.02 \\
\hline Swedes (Central, S) ${ }^{2}$ & 604 & 0.03 & 0.01 \\
\hline Swedes (Gotland) ${ }^{2}$ & 574 & 0.03 & 0.03 \\
\hline Danes $^{4}$ & 1096 & 0.03 & 0.03 \\
\hline Norwegians ${ }^{4}$ & 4492 & 0.02 & 0.03 \\
\hline Irish $^{5}$ & 1100 & 0.02 & 0.05 \\
\hline English people ${ }^{4}$ & 4775 & 0.01 & 0.03 \\
\hline Germans ${ }^{4}$ & 5886 & 0.01 & 0.02 \\
\hline French $^{4}$ & 8753 & 0.01 & 0.08 \\
\hline Hungarians ${ }^{4}$ & 1036 & 0.01 & 0.03 \\
\hline Dutch $^{4}$ & 2539 & 0.01 & 0.02 \\
\hline Estonians $^{2}$ & 1850 & 0.03 & 0.01 \\
\hline Finns ${ }^{4}$ & 2112 & 0.01 & 0.01 \\
\hline
\end{tabular}

${ }^{1}$ Maliseva et al., 2002; ${ }^{2}$ Beckman et al., 1999; ${ }^{3}$ Gailite (Piekuse), unpublished data; ${ }^{4}$ Blanco et al., 2006; ${ }^{5}$ Carroll et al., 2011

accounts for $73 \%$ of Latvian PKU chromosomes. The same prevalence of this mutation is found in the Lithuanian population and is even higher (84\%) in the Estonian population. R408W-2.3 is the main haplotype for mutation R408W not only in Latvians and Lithuanians, but also in Estonian, Polish, and German populations. The frequency of R408-2.3 suggests a Balto-Slavic origin of this R408W mutation or its association with a pre-Indo-European founder population (Tighe et al., 2003; Pronina and Lugovska, 2011).

Gene SERPINA1, alleles PIZ and PIS. Gene SERPINA1 (OMIM *107400) encodes protein alpha-1-antitrypsin (AAT), a major plasma serine protease inhibitor. Alpha-1antitrypsin deficiency (OMIM \#613490) is one of the most common autosomal recessive inborn errors of metabolism in people of European ancestry, which is caused by muta- 
tions in the gene SERPINA1. AAT deficiency often is associated with an early onset of obstructive lung disease and emphysema in adulthood, and liver disease in children. The most frequent AAT deficiency alleles (mutations) are PIZ and PIS. The most common mutation presenting with clinical evidence is the $\mathrm{Z}$ mutation (E342K), caused by a single amino acid replacement of glutamic acid at position 342 of the polypeptide, while $\mathrm{S}$ mutation is associated with a milder plasma deficiency of AAT protein. Throughout Europe the frequency of $\mathrm{Z}$ and $\mathrm{S}$ mutations in healthy individuals varies widely between countries. $\sim 3-4 \%$ of NorthEuropeans carry the $\mathrm{Z}$ allele whereas $6 \%$ carry $\mathrm{S}$ allele. Frequency of the PIZ allele in Latvia detected by isoelectric focusing in 488 individuals was 0.040 (Beckman et al., 1999), but by more precise DNA analysis in 270 individuals gave an estimate of 0.034 (Mališeva et al., 2002; Table 3), which are the highest population frequencies reported so far in Europe. The calculated frequency of PIZ carriers is $1: 30$; approximately $3 \%$ of the Latvian population are carriers of the mutation PIZ. Frequencies of the PIS allele in Latvia were estimated to be 0.026 (isoelectric focusing, Beckman et al., 1999) and 0.032 (DNA analysis, Mališeva et al., 2002; Table 3), which are higher than the average allele PIS frequency in Central Europe, but significantly lower than in South European countries. Noteworthy is the fact that the highest frequency of PIZ allele is reported in the NorthWestern part of Latvia (Northern Curonian region). High frequencies are also found on the Swedish mainland and on the Island of Gotland. Relatively high frequencies are observed in Estonians, as well as in the North-Western regions of Archangelsk and Vologda in Russia (Gailite (Piekuse), unpublished data), whereas in Finns and people of Central European part of Russia the frequencies are considerably lower. There is a remarkable and highly significant difference between Latvians and Lithuanians with respect to PIZ allele frequency. In this context it is of interest that archaeological data have shown that from the $7^{\text {th }}$ century and for several hundreds of years there were several settlements of people from Swedish mainland as well as from the Island of Gotland in the Grobina area on the Curonian coast of the Baltic Sea (Radiňš, 2012). The PIZ variant in Latvia and Sweden shared a unique genotype that was not present in the control population (Lace et al., 2008). This single genotype confirmed the hypothesis of a recent and single origin of the PIZ mutation. Analysis of non-recombinant single nucleotide polymorphisms (SNPs) was used to estimate that the PIZ mutation age was 2902 years in Latvia and 2362 years in Sweden. The authors speculate that the possible route of this allele was from Sweden (southern Scandinavia) to other countries, including the Baltic countries, where it spread through the waterways into the continent by migration patterns such as the Viking colonisation of NorthWestern Europe between 800 and 1200 AD (Hutchison, 1998). In any case, the allele PIZ is a good marker for Southern Sweden and Latvian genetic influence. The S mutation is older than the $\mathrm{Z}$ mutation and is postulated to have arisen in the north of the Iberian Peninsula and subsequently spread throughout Europe during the mass migration (Seixas et al., 2001).
Gene HFE, alleles C282Y and H63D. Gene HFE (OMIM *613609) codes for HFE protein that participates in the regulation of iron absorption. Mutations in this gene may lead to hereditary haemochromatosis (HH s. HFE-associated hereditary haemochromatosis, OMIM \#235200), an inborn error of iron metabolism. HH belongs to the most common autosomal recessive disorders in people of European ancestry, characterised by iron overload and failure of different organs. Most HH patients are homozygotes for the missense mutation $\mathrm{C} 282 \mathrm{Y}$ that leads to the substitution of tyrosine for cysteine at amino acid 282. The role of another missense mutation, H63D, is still unclear (compound heterozygotes with $\mathrm{C} 282 \mathrm{Y}$ have haemochromatosis). The average frequencies of mutation $\mathrm{C} 282 \mathrm{Y}$ and H63D carriers among healthy Latvians are $3.5 \%$ and $12.1 \%$, respectively, which is similar to the average frequency in Lithuanians and Estonians, but lower than in most populations of Northern Europe (Krumina et al., 2001a; Kucinskas et al., 2012; Table 3). The frequency of C282Y mutation is significantly higher among the inhabitants of Žemaitija at the Baltic Sea area $(5.9 \%)$ in comparison to the regions of the continental part of Lithuania (Kučinskas et al., 2012). The highest frequency is observed in Ireland (11.4\%) and in the eastern part of England (8.2\%), and a slightly lower frequency in Norway, Sweden, Denmark, and Iceland. The lowest reported frequencies (0-1.75\%) of the $\mathrm{C} 282 \mathrm{Y}$ mutation were observed in Greece, Romania, and Bulgaria (Merryweather-Clarke et al., 1997; Ivanova et al., 1999; Voicu et al., 2009). These data support the hypothesis of gene flow from north to south of Europe. Most scientists agree that mutation C282Y appeared 60-70 generations ago (Ajioka et al., 1997) and originated from the population of Southern Scandinavia or Northern Germany (Distante et al., 2004). It has also been suggested that Viking migrations were largely responsible for the distribution of this mutation. The H63D mutation is more common and equally distributed among European nations. The highest frequency of this mutation has been reported in the Basque population (30.4\%) and genetic data suggest that this mutation could have originated in early Western European populations (de Juan et al., 2001).

Gene CCR5, allele CCR5- $\Delta$ 32. Gene CCR5 (OMIM *601373) encodes cell membrane protein C-C chemokine receptor 5 (CCR5), which is the principal entry co-receptor for macrophage-tropic human immunodeficiency virus type 1 (HIV-1) strains. Mutation CCR5- $\Delta 32$ (CCR5-delta32) is a 32 bp deletion in this gene and results in a frame shift in the coding sequence that produces a non-functional protein, and consequently it is not expressed in the cell membrane. Individuals homozygous for the mutation show high degree of resistance to HIV infection. Heterozygous carriers have reduced susceptibility to infection and reveal a slowed progression towards AIDS. The results of screening of more than 2500 individuals from 18 European populations suggested a unique and relatively recent origin of this allele, which probably arose in North-Eastern European populations (Libert et al., 1998; Klitz et al., 2001). The age of the $\Delta 32$ allele has been estimated between 700 and 3500 years based on linkage disequilibrium data (Stephens et al., 1998; 
FREQUENCIES OF GENE HFE ALLELES C282Y AND H63D IN EUROPEAN POPULATIONS

\begin{tabular}{c|c|c|c}
\hline Populations & $\mathrm{n}$ & $\begin{array}{c}\text { HFE gene } \\
\text { allele C282Y } \\
\text { (rs1800562) }\end{array}$ & $\begin{array}{c}\text { HFE gene } \\
\text { allele H63D } \\
\text { (rs1799945) }\end{array}$ \\
\hline
\end{tabular}

Latvians $^{1}$

0.03

0.11

CE 71

0.03

0.15

SW 71

0.04

0.05

Total 295

0.04

0.12

0.12

Lithuanians $^{2}$

$\begin{array}{rc}\text { Žemaitija } & 102 \\ \text { East Aukštaitija } & 378 \\ \text { West Aukštaitijai } & 148 \\ \text { South Aukštaitijai } & 383 \\ \text { Total } & 1011\end{array}$

0.06

0.02

0.02

0.02

0.03

0.04

0.04

0.03

0.03

0.03

0.06

0.06

0.11

0.06

0.08

0.04

0.01

0.03

0.04

0.05

nda

nda

nda

nda

0.16

0.13

0.16

0.17

0.16

0.15

0.13

0.14

0.15

0.11

0.13

0.15

0.13

0.17

0.14

0.12

Finns ${ }^{1}$

nda, no data available; ${ }^{1}$ data from Krumina et al., 2001a; ${ }^{2}$ data from Kucinskas et al., 2012; ${ }^{3}$ Sivitskaya et al., 2013, ${ }^{4}$ Pampukha et al., 2003, ${ }^{5}$ Milman et al., 2004, ${ }^{6} 1000$ Genomes Browser

Slatkin, 2001), and ancient DNA evidence suggests that the allele is at least 2900 years old (Hummel et al., 2005). The highest frequencies were registered in Mordvins, Estonians, Finns, Belarusians, Latvians, as well as in North-European Russians, the last populations being supposed to have a strong Finno-Ugric background, maximum in areas surrounding the Baltic and White Seas (the area of highest frequency lies between the Baltic and the White Seas; Table 5). High frequency is registered also in central Russia near Novosibirsk (Balanovsky et al., 2005). If $\Delta 32$ were neutral, population genetics theory, given allele's frequency, predicts that it would have to be much older. An alternative explanation is that $\Delta 32$ mutation occurred recently and afterwards increased rapidly in frequency because of a strong selective advantage (Libert et al., 1998; Stephens et al., 1998). Bubonic plague was initially proposed as the selective agent, but subsequent analysis suggested that a disease like smallpox is a more plausible candidate (Galvani and Slatkin, 2003; de Silva and Stumpf, 2004; Stumpf and
FREQUENCIES OF GENE CCR5 ALLELE CCR5- 32 IN EUROPEAN POPULATIONS

\begin{tabular}{lr|c|c}
\hline \multicolumn{1}{c|}{ Populations } & $\mathrm{n}$ & $\begin{array}{c}\text { CCR5 gene allele } \\
\Delta 32(\mathrm{rs} 333)\end{array}$ \\
\hline Latvians $^{1}$ & & & \\
& $\mathrm{NW}$ & 91 & 0.12 \\
& $\mathrm{CE}$ & 70 & 0.19 \\
& $\mathrm{SW}$ & 51 & 0.15 \\
& $\mathrm{E}$ & 68 & 0.17 \\
& Total & 156 & 0.15 \\
Lithuanians $^{2}$ & & 283 & 0.12
\end{tabular}

Russians (NW) ${ }^{1}$

$$
\begin{array}{r}
\text { Staritsa, Tver Oblast } \\
\text { Sychevka, Smolensk Oblast } \\
\text { Ustyuzhna, Vologda Oblast } \\
\text { Mezen, Archangelsk Oblast } \\
\text { Total (NW) }
\end{array}
$$

Russians (Moscow) $)^{2}$

Russians (Ryazan) ${ }^{2}$

Belarusians $^{2}$

Ukrainians $^{2}$

Poles $^{3}$

Czechs $^{3}$

Danes $^{2}$

Norwegians $^{3}$

Irish $^{3}$

Swedes $^{2}$

English people ${ }^{3}$

Germans $^{3}$

Italians $^{2}$

French $^{2}$

Mordvins $^{2}$

Estonians $^{3}$

Finns $^{2}$

$\begin{array}{rl}97 & 0.11 \\ 86 & 0.14 \\ 95 & 0.10 \\ 123 & 0.10 \\ 401 & 0.11 \\ 50 & 0.14 \\ 78 & 0.12 \\ 80 & 0.16 \\ 83 & 0.11 \\ 1005 & 0.12 \\ 547 & 0.11 \\ 100 & 0.12 \\ 183 & 0.12 \\ 191 & 0.08 \\ 204 & 0.14 \\ 705 & 0.12 \\ 307 & 0.11 \\ 91 & 0.06 \\ 276 & 0.09 \\ 86 & 0.16 \\ 662 & 0.14 \\ 98 & 0.16\end{array}$

${ }^{1}$ Gailite (Piekuse) unpublished data; ${ }^{2}$ Limborska et al., 2002; ${ }^{3}$ Faure and Royer-Carenzi, 2008

Wilkinson- Herbots, 2004; Galvani and Novembre, 2005). Analysis performed on CCR5 polymorphisms in Russian, Ukrainian, and Moldavian populations showed a strong positive correlation between allele frequency and latitude, and a set of temperature factors (Limborska et al., 2002). The authors proposed that the existence of correlations between the cline of $\Delta 32$ frequencies and climatic-geographic parameters provided evidence for a possible effect of either natural environmental factors (geographical gradient in selection intensity) or large-scale population movements on distribution of this allele. Other authors (Balanovsky et al., 2005) proposed a rise and initial spread of the mutation among Uralic-speaking populations, in particular in its Finnic branch, a frequency increase in North-Eastern Europe as a result of selection and/or genetic drift, and secondary spread (with selection continued) due to gene flow and the migrations of North Europeans across the globe. 
Gene ICAM4, allele $\mathbf{L W}^{\mathbf{b}}$. ICAM4 (LW) gene (OMIM *614088) encodes single-pass membrane glycoprotein called intercellular adhesion molecule 4. LandsteinerWiener (LW) blood group antigens (OMIM \#111250) reside on this protein. There are three antigens assigned to the LW system: $\mathrm{LW}^{\mathrm{a}}, \mathrm{LW}^{\mathrm{b}}$, and $\mathrm{LW}^{\mathrm{ab}}$ (Byrne and Byrne, 2004; Srivastava et al., 2014). $\mathrm{LW}^{\mathrm{a}}$ and $\mathrm{LW}^{\mathrm{b}}$ antigens are antithetical, resulting from a single nucleotide substitution in the ICAM4 gene $(299 \mathrm{~A}>\mathrm{G})$, which causes an amino acid change in LW glycoprotein (Q100R).

LW blood group polymorphism has been widely tested by antigen detection (Sistonen et al., 1999). Population genetic studies on the LW blood group by standard serological methods resulted in a conclusion that the $\mathrm{LW}^{\mathrm{b}}$ antigen was found in Europeans only, presenting the highest frequency in the Baltic-speaking Latvian and Lithuanian populations, leading to the conclusion that this polymorphism can be considered as a "Baltic tribe marker" (Kučinskas et al., 1998; Sistonen et al., 1999; Kučinskas, 2001). Recent advances in DNA analysis allowed to trace $\mathrm{LW}^{\mathrm{b}}$ allele frequency distribution for several populations, not previously included in studies by serological methods (the $1000 \mathrm{Ge}$ nomes Project). The $\mathrm{LW}^{\mathrm{b}}$ allele was not found or was found at very low frequencies in most African, Native American, Asian, and West-European populations. Frequencies of $\mathrm{LW}^{\mathrm{b}}$ allele in different European populations are presented in Table 6. The highest frequency was found in Lithuanians, followed by two subpopulations of Latvians, Estonians, Belarusians, and Russians. It follows from the frequency distribution that $\mathrm{LW}^{\mathrm{b}}$ frequency displayed a steady continuous decrease trend in all directions away from the central area of the Balts. The $\mathrm{LW}^{\mathrm{b}}$ allele is found also in other Slavicspeaking populations, in particular the Poles. This fact may reflect the peculiarities of the ethnic history of Slavs: the presence of $\mathrm{LW}^{\mathrm{b}}$ allele may reflect the admixture with the Baltic-speaking populations, if the mutation originated from the Balts, or revealing a trace of an ancient autochthonous community that existed in the territory of East-European plain up to the Baltic Sea. The peculiar geographical distribution of $\mathrm{LW}^{\mathrm{b}}$ allele, with relatively high frequencies in the Balts and zero or almost zero levels in Asiatic, African, and West-European populations (The 1000 Genomes Project), makes this blood group a very informative marker for Baltic genetic influence. This means that its presence in other populations is likely to be due to Baltic admixture.

Gene MCM6, allele 13910*T. Gene MCM6 (OMIM *601806) encodes protein minichromosome maintenance complex component 6 , which participates in the replication of eukaryotic DNA. Gene MCM6 in humans is located upstream from the lactase gene LCT (OMIM *603202) and regulates its transcription. Gene $L C T$ encodes enzyme lactase, which catalyses the hydrolysis of lactose, the main carbohydrate in milk, to monosaccharide glucose and galactose. Lactase activity in new-born mammals is high. In adult mammals, including humans, lactase persistence (LP) or lactose tolerance normally disappears after weaning. LP is an autosomal dominant trait enabling continued produc- tion of lactase throughout adult life. Lactase non-persistence (lactose intolerance, lactase deficiency, adult type hypolactasia), which is an ancestral condition for all mammals, is an autosomal recessive trait (OMIM \#223100). The degree and symptoms of lactose intolerance vary individually, and most lactose intolerant individuals can usually tolerate small amounts of lactose. The geographic distribution of LP matches the distribution of dairy farming: LP is common in North-European populations (increase from southeast to northwest across Europe), as well as in some pastoralist populations from Africa and the Middle East (Scrimshaw and Murray, 1988; Laland et al., 2010). In European populations, two dominant alleles in the gene MCM6 that directly affect $L C T$ gene promoter activity and are tightly associated with LP are found: -22018*A (rs182549) in intron 9, and $-13910 * \mathrm{~T}$ (rs4988235) in intron 13 (Enattah et al., 2002). In Europeans the best studied is the association of LP with the genotypes $\mathrm{C} / \mathrm{T}$ and $\mathrm{T} / \mathrm{T}$ in the above-mentioned locus -13910. Frequencies of MCM6 gene allele -13910*T in Latvians and other European populations as well as frequencies of LP are shown in Table 7. The highest frequencies are observed in North Western and Northern Europe: in Irish, Swedes, Finns, Danes, and English. It is estimated that allele $-13910 * \mathrm{~T}$ derived from the ancestral allele $-13910 * \mathrm{C}$ during the past $6100-7500$ years within Central Europeans, probably in response to selection for the ability to digest milk as adults (Bersaglieri et al., 2004). Allelic age estimates are consistent with the results of an ancient DNA study, which showed that allele $-13910 * \mathrm{~T}$ was rare or absent among early farmers from Central and Eastern Europe (Burger et al., 2007). The observed high frequencies of allele $-13910^{*} \mathrm{~T}$ in Northern Europe can best be explained by strong selection that took place in Neolithic Central Europe and was followed by a migration of people representing this culture to Northern Europe (Vuorisalo et al., 2012). The immigrants gradually replaced or were assimilated by the local hunter-gatherer populations. The low frequencies of MCM6 gene $-13910 * \mathrm{~T}$ allele and lactase persistence in Latvians and North-Western Russians may be explained by the relatively recent transition from Mesolithic to Neolithic in the Baltic region, which was not driven by admixture with early European farmers (Jones et al., 2017). The analysis of ancient DNA has shown that the transition from Mesolithic to Neolithic is also the period when first derived MCM6 allele, which is associated with lactase persistence, is found in Latvia. There is increased frequency of the derived alleles in the Bronze Age samples (0.50 in 9 Latvian individuals) (Table 1, Jones et al., 2017; Mittnik et al., 2017a; 2017b).

\section{MITOCHONDRIAL DNA VARIATION}

Mitochondrial DNA (mtDNA) - matrilineal - genetic variation was investigated by Pliss et al., 2006 in a sample of 299 (in her PhD thesis - 351) healthy unrelated Latvians representing the above-mentioned four different regions of Latvia. Sequencing of the first mtDNA hypervariable segment (HVS-I) in combination with analysis of informative coding region markers revealed that the vast majority of the 
FREQUENCIES OF GENE ICAM4 ALLELE LW ${ }^{\mathrm{B}}$ (RS77493670) IN EUROPEAN POPULATIONS

\begin{tabular}{|c|c|c|}
\hline Populations & $\mathrm{n}$ & $\begin{array}{l}\text { gene ICAM4 allele } \\
\text { LW }^{\mathrm{b}}(\text { rs } 77493670)\end{array}$ \\
\hline \multicolumn{3}{|l|}{ Latvians ${ }^{1}$} \\
\hline NW & 84 & 0.05 \\
\hline $\mathrm{CE}$ & 67 & 0.02 \\
\hline SW & 36 & 0.03 \\
\hline $\mathrm{E}$ & 75 & 0.06 \\
\hline Total & 262 & 0.04 \\
\hline \multicolumn{3}{|l|}{ Lithuania $^{1}$} \\
\hline Žemaitija & 84 & 0.07 \\
\hline East Aukštaitija & 38 & 0.05 \\
\hline West Aukštaitija & 29 & 0.04 \\
\hline South Aukštaitija & 34 & 0.03 \\
\hline Total & 185 & 0.06 \\
\hline Russians (Vologda) ${ }^{2}$ & 383 & 0.02 \\
\hline Belarusians $^{1}$ & 60 & 0.03 \\
\hline Poles $^{2}$ & 749 & 0.02 \\
\hline Swedes (Central) ${ }^{2}$ & 395 & 0.01 \\
\hline English people ${ }^{3}$ & 91 & 0.01 \\
\hline Italians $^{3}$ & 100 & 0 \\
\hline Estonians $^{2}$ & 800 & 0.04 \\
\hline Finns $^{2}$ & 908 & 0.03 \\
\hline
\end{tabular}

observed mtDNA variants in Latvians belong to haplogroups (hgs) como most European populations (Table 8). One hundred and twenty four different haplotypes (nucleotide sequence variants within haplogroups) belonging to 11 major hgs were observed. $\mathrm{HgH}$, which is the most frequent hg in European populations, accounted for almost half (43.3\%) of mtDNA variants in Latvians. $45 \%$ of the classified hg $\mathrm{H}$ cases belonged to sub-hgs $\mathrm{H} 1$ and H5. Sub-hg H1b, which occurs more frequently in Eastern and Central North Europe, was the most abundant type of sub-hg H1 among Latvians, also being frequent among Estonians. The HVS-I sequence motifs characteristic to this sub-hg can often be observed also in the Lithuanian population (Kasperavičiūte et al., 2004). In the Latvian gene pool, H1b was significantly more frequent than among Eastern Slavs (Loogväli et al., 2004). Significant differences of H1a frequencies were observed between Latvians and Finns (the statistical significance of population differences for mtDNA data is taken from Pliss et al., 2006). Among the Finns, sub-hg H1b was not observed. On the other hand, sub-hg H1f, frequent in the Finnish population, was not found in the Latvian mtDNA pool. Sub-hg H5, the second largest in the Latvian mtDNA pool (15\% of H), was found to be significantly more frequent among Latvians than in the gene pool of hg H in Eastern Slavs. A quarter of mtDNA variants belonged to hg U. Five sub-hgs (U2, U3, U4, U5 and U8) were observed among hg U haplotypes. The sub-hgs U4 and U5 were most abundant, covering about $40 \%$ of the hg U
FREQUENCIES OF GENE MCM6 ALLELE -13910*T IN EUROPEAN POPULATIONS

\begin{tabular}{|c|c|c|c|}
\hline Populations & $\mathrm{n}$ & $\begin{array}{c}\text { MCM6 gene } \\
-13910 * \text { T allele } \\
\text { frequency } \\
\text { (rs4988235) }\end{array}$ & $\begin{array}{l}\text { Lactase } \\
\text { persistence } \\
\text { frequency }\end{array}$ \\
\hline \multicolumn{4}{|l|}{ Latvians ${ }^{1}$} \\
\hline NW & 86 & 0.37 & nda \\
\hline $\mathrm{CE}$ & 67 & 0.32 & nda \\
\hline SW & 56 & 0.34 & nda \\
\hline $\mathrm{E}$ & 68 & 0.30 & nda \\
\hline Total & 277 & 0.34 & 0.55 \\
\hline Lithuanians & & $0.32^{9}$ & 0.61 \\
\hline \multicolumn{4}{|l|}{ Russians (NW) ${ }^{1}$} \\
\hline Staritsa, Tver Oblast & 21 & 0.38 & nda \\
\hline Sychevka, Smolensk Oblast & 29 & 0.33 & nda \\
\hline Ustyuzhna, Vologda Oblast & 40 & 0.36 & nda \\
\hline Mezen, Archangelsk Oblast & 32 & 0.44 & nda \\
\hline Total & 122 & 0.38 & \\
\hline Russians (Central) & 50 & $0.24^{2}$ & 0.43 \\
\hline Belarusians & & nda & 0.62 \\
\hline Ukrainians & & nda & 0.54 \\
\hline Poles & 289 & $0.46^{7}$ & 0.63 \\
\hline Czechs & & nda & 0.82 \\
\hline Irish & 65 & $0.95^{3}$ & 0.96 \\
\hline Swedes (Central, S) & 360 & $0.82^{2}$ & 0.96 \\
\hline Norwegians & & nda & 0.96 \\
\hline Danes & 97811 & $0.76^{8}$ & 0.96 \\
\hline English people & 3344 & $0.75^{4}$ & 0.95 \\
\hline Germans & 60 & $0.56^{3}$ & 0.85 \\
\hline Italians (North) & 28 & $0.36^{2}$ & 0.49 \\
\hline Italians (Middle) & 16 & $0.06^{2}$ & nda \\
\hline French & 58 & $0.43^{2}$ & 0.71 \\
\hline Estonians & 355 & $0.51^{5}$ & 0.64 \\
\hline Finns $^{2}$ & 360 & $0.82^{2}$ & 0.84 \\
\hline
\end{tabular}

nda, no data available; ${ }^{1}$ Gailite (Piekuse), unpublished data; ${ }^{2}$ Bersaglieri et al., 2004; ${ }^{3}$ Itan et al., 2009; ${ }^{4}$ Smith et al., 2009; ${ }^{5}$ Lember et al., 2006; ${ }^{6}$ Cook, 2014; ${ }^{7}$ Madry et al., 2011; ${ }^{8}$ Bergholdt et al., 2015; ${ }^{9}$ Kalibatiene et al., 2006

gene pool. Comparison of mtDNA hg profiles in different European populations (Table 7) showed that the frequency of hg U4 was significantly higher in Eastern than in Western European populations. Interestingly, the frequency of sub-hg U4 in Latvians is among the highest in Europe. In the central part of Latvia (Semigalia), U4 was found in $14.9 \%$ of all mtDNA variants. Pliss et al. (2006) noted that the heterogeneity of hg U4 is also relatively high in Semigalia: of thirteen U4 haplotypes found among Latvians eight were discovered in this region. Another example of only few region-specific differences in the Latvian mtDNA pool is provided by sub-hg U2, which has a particularly high frequency in Eastern Latvia; seven of nine Latvian sub-hg U2 mtDNAs were found in Latgalia. The frequency of U2 was significantly higher in Latgalia than in the western parts of 
MITOCHONDRIAL DNA HAPLOGROUP FREQUENCIES (\%) AMONG LATVIANS AND OTHER EUROPEAN POPULATIONS

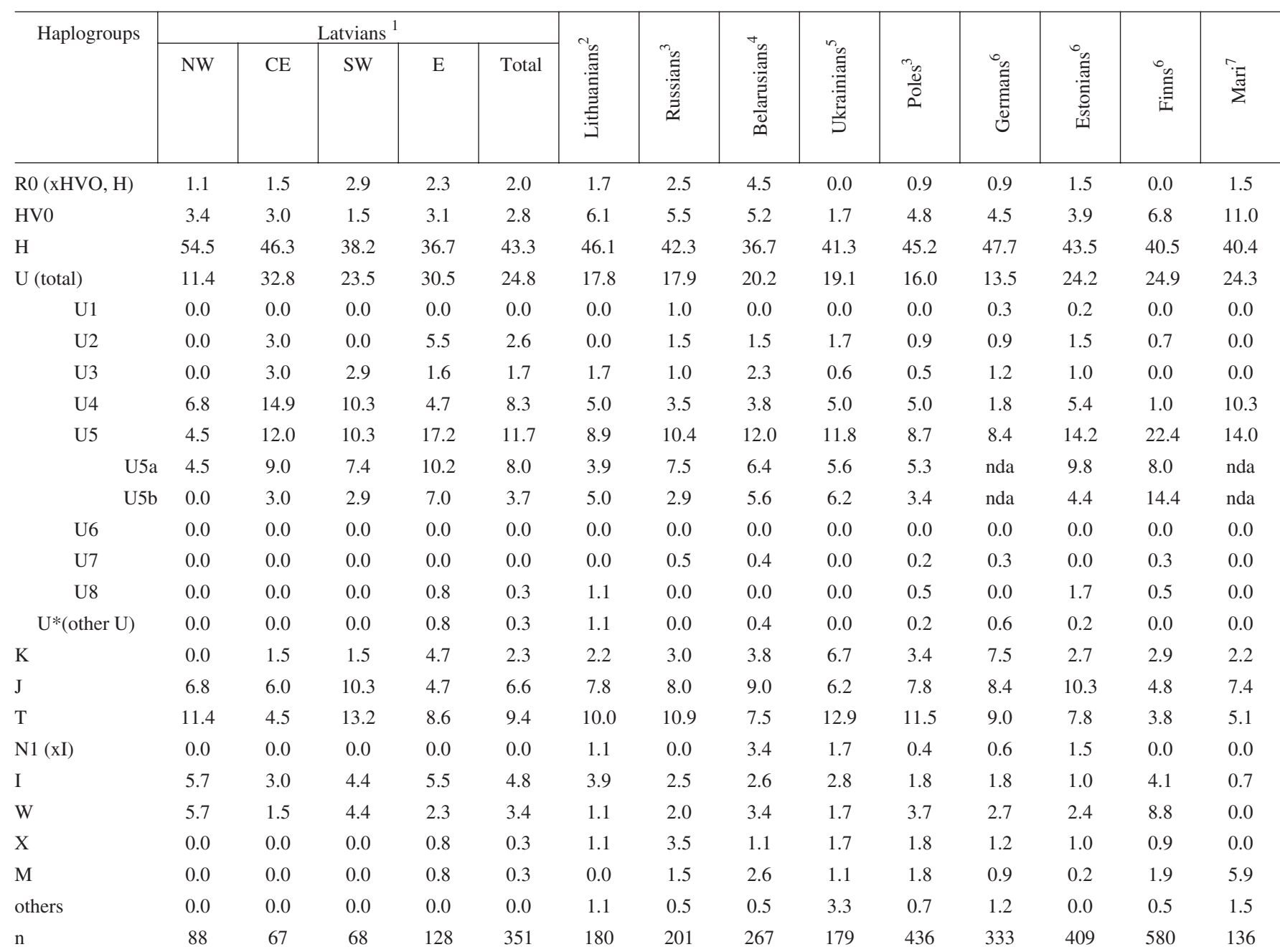

nda, no data available; ${ }^{1}$ Pliss, 2007; ${ }^{2}$ Kasperavičiūte et al., 2004; ${ }^{3}$ Malyarchuk et al., 2002; ${ }^{4}$ Kushniarevich et al., $2013 ;{ }^{5}$ Kushniarevich et al., $2015 ;{ }^{6}$ data from Pliss et al., 2006; ${ }^{7}$ Bermisheva et al., 2002

Latvia (Northern and Southern Curonia). The authors suggested that the high frequency of hg U2 in Latgalia could be best explained by a recent founder effect, because all U2 samples found belonged to the same HVS-I haplotype. Similar intra-population homogeneity was also observed among Lithuanians (Kasperavičiūte et al., 2004). U5a, another frequent haplogroup ( $8.0 \%$ in Latvians), is more typical for Eastern Europeans compared to Central and SouthEastern Europe, whereas haplogroup U5b (3.7\% in Latvians) reflects the input from South-Western and Central Europe (Malyarchuk et al., 2010). The other hg that has a different frequency pattern in Eastern and Western European populations (Table 8 ) is $\mathrm{K}$; statistically significant differences of hg $\mathrm{K}$ frequencies were observed between Latvians and Western European populations, with hg $\mathrm{K}$ being more common among the latter. Only a single member of Asian-specific hg M (G2a) was found in Latgalia, the eastern part of Latvia. In Northern Europe, the two main hg M lineage groups are D5b and Z1, although they are present in many populations at low frequencies (Tambets et al., 2004).
Interestingly, these hgs were observed neither in the sample of 351 Latvians, nor among 225 Lithuanians (Kasperavičiūte et al., 2004; Tambets et al., 2004). One D5b individual has been found among 545 Estonians (Tambets et al., 2004). This observation is of some interest because the northward Finnic-speaking populations, Finns, Saami, and Karelians, possess East Asian maternal lineages at frequencies that are low, but still higher (2\%-5\%) (Sajantila et al., 1995; Tambets et al., 2004) than in the populations inhabiting the South-Eastern Baltic coast. Pliss et al. (2006) suggested that East Asian maternal gene flow had, in Eastern Europe, only a negligible impact on populations living in the South-Eastern Baltic Sea region, although it reached populations living close to the sub-Arctic fringe of Europe.

To illustrate the genetic relationships of studied populations, principal component (PC) analysis based on the frequencies of mtDNA hgs from Table 8 was performed (Fig. 6). The analysis showed that all compared European populations, except Finns and Mari, fall into one cluster. Latvi- 


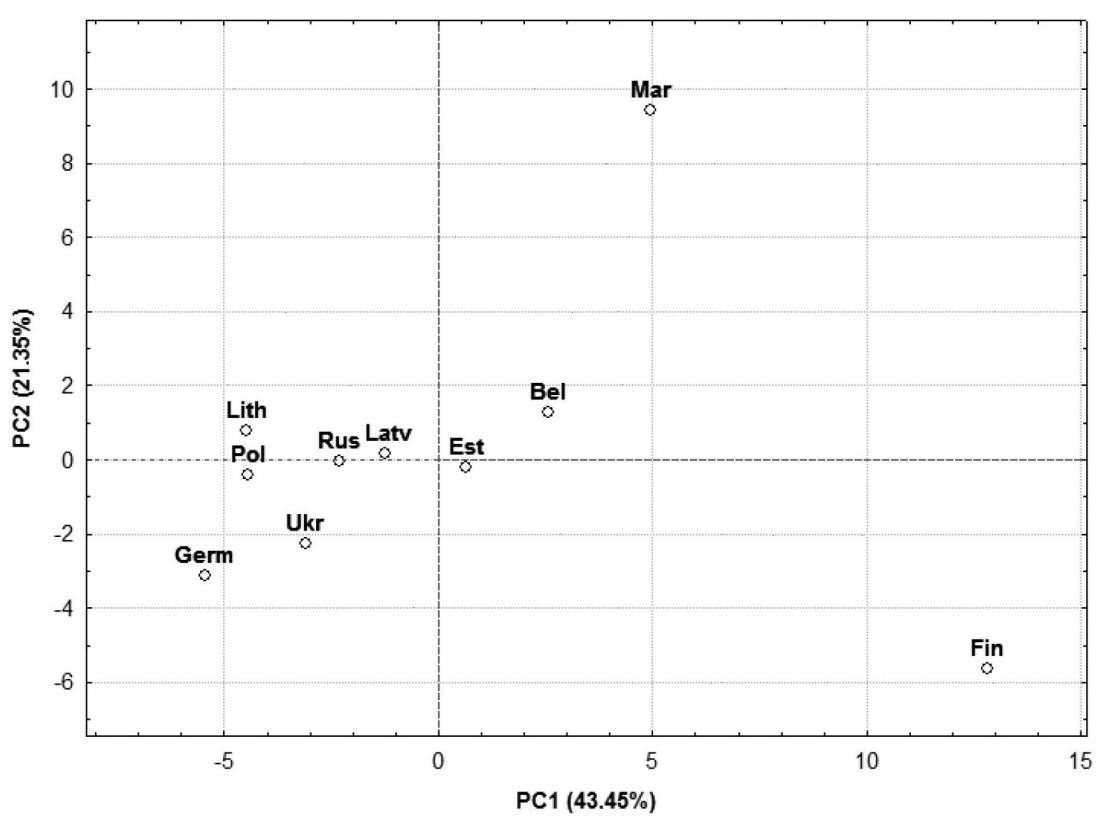

Fig. 6. Principal component analysis (PCA) based on mtDNA haplogroup frequencies in some European populations. Population codes are given in alphabetical order as follows: Bel, Belarusians; Est, Estonians; Fin, Finns; Ger, Germans; Lat, Latvians; Lit, Lithuanians; Mar, Maris; Pol, Poles; Rus, Russians; Ukr, Ukrainians. The genetic variation retained by different components is shown in brackets. ans and Lithuanians formed a relatively tight cluster with Estonians, Russians, Poles, and Belarusians.

The HVS-I haplotype-sharing analysis performed by Pliss et al. (2006) among Baltic-, Germanic-, Slavic-, and FinnoUgric speaking populations showed that the vast majority of mtDNA haplotypes found among Latvians are identical to, or close derivatives of, those observed in other Eastern and Western European populations, irrespective of their linguistic affiliations. These results most likely reflect a deep common origin for the European mtDNA pool (Richards et al. 1996). It might be that no significant differences in mtDNA variability between founder populations existed in the period of formation of the Balts; therefore one cannot distinguish different components of founders in the present day populations.

The recent development of high-throughput sequencing of mtDNA genomes has revealed some matrilineal gene pool substructure in Europe which was not detected using only HVS1 sequences and low resolution haplogroup information (Torron et al., 2006). In order to obtain important additional information on modern Latvian mtDNA pool, future analysis of high resolution data is needed.

It seems important that in recent analysis of twenty-one ancient Mesolithic and Neolithic DNA samples from the Zvejnieki burial site in Northern Latvia, all of them belonged to typically hunter-gatherer haplogroup $\mathrm{U}$ : eleven to sub-lineage U5a, two - U5b, seven - U4, one - U2 (Jones et al., 2017, Mathieson et al., 2017; Table 1). Haplogroup $\mathrm{U}$ is found in most European hunter-gatherer samples (Skoglund et al., 2012; Brandt et al., 2013; Posth et al., 2016). No mitochondrial haplogroups that are typical for Central European Mesolithic/Neolithic farmers were detected in the territory of today's Latvia. The Bronze Age individuals from Kivutkalns burial display a more diverse set of mitochondrial haplogroups, besides $\mathrm{U}$, including also $\mathrm{H}$ (different sublineages), $\mathrm{J}$ and $\mathrm{T}$, which first appeared in
Europe during the Neolithic (Mittnik et al., 2017a; 2017b; Table 1).

\section{NRY VARIATION}

Several studies of Y-chromosomal - patrilineal - variability in the Latvian population have been conducted, based on biallelic markers and short tandem repeats (STRs). Contrary to mtDNA data, analysis of Y-chromosome lineages has revealed deeper differences between the studied NorthEastern European populations. Rosser et al. (2000) on analysis of 11 biallelic NRY polymorphisms in 47 European populations (including Latvians) concluded that Ychromosomal diversity in Europe is clinal and influenced primarily by geography, rather than by language. Based on the analysis of both Y-chromosome haplogroup frequency distribution and microsatellite variation, Zerjal et al. (2001) hypothesised that $\mathrm{Y}$ chromosomes of Finno-Ugric- and Baltic-speaking populations have distinct genetic histories. These results were confirmed by Lessig et al. (2001) and Kasperavičiūte et al. (2004). They noted, however, that it is unclear whether the observed differences suggested different source populations or rather more recent random genetic drift. The analysis of five biallelic Y-chromosomal markers performed by Laitinen et al. (2002), on the other hand, demonstrated a high genetic similarity between Estonian, Latvian, Lithuanian, and Finno-Ugric-speaking Mari males, leading to the suggestion that Baltic males share common Finno-Ugric-speaking forefathers (Laitinen et al., 2002). The genotyping of DNA samples subsequently performed by Lappalainen et al. (2008) on a larger group of markers (18 Y-chromosomal biallelic polymorphisms and 9 STRs) confirmed differences in the haplotype structure of Balticspeaking Latvians and Lithuanians and Finno-Ugric populations, allowing to suggest at least two main migration waves to the Baltic Sea region (Lappalainen et al., 2008). Kushniarevich et al. (2015) in analysis of 40 binary NRY markers found that both extant Baltic-speaking populations, Latvi- 
NRY HAPLOGROUP FREQUENCIES (\%) IN LATVIANS AND COMPARABLE EUROPEAN POPULATIONS

\begin{tabular}{|c|c|c|c|c|c|c|c|c|c|c|c|c|c|c|c|c|}
\hline \multirow{2}{*}{$\begin{array}{l}\text { Haplo- } \\
\text { group }\end{array}$} & \multirow[t]{2}{*}{ Markers } & \multicolumn{5}{|c|}{ Latvians ${ }^{1}$} & \multirow{2}{*}{$\begin{array}{l}\text { Lithua- } \\
\text { nians }^{2}\end{array}$} & \multirow{2}{*}{$\begin{array}{c}\text { Rus- } \\
\text { sians } \\
\text { North- } \\
\text { ern }^{3}\end{array}$} & \multirow{2}{*}{$\begin{array}{c}\text { Rus- } \\
\text { sians } \\
\text { Central }^{3}\end{array}$} & \multirow{2}{*}{$\begin{array}{c}\text { Bela- } \\
\text { rusians }\end{array}$} & \multirow{2}{*}{$\begin{array}{l}\text { Ukrai- } \\
\text { nians } 5\end{array}$} & \multirow[t]{2}{*}{ Poles $^{6}$} & \multirow{2}{*}{$\begin{array}{l}\text { Ger- } \\
\text { mans }^{6}\end{array}$} & \multirow{2}{*}{$\begin{array}{c}\text { Esto- } \\
\text { nians }^{2}\end{array}$} & \multirow[t]{2}{*}{ Finns $^{2}$} & \multirow[t]{2}{*}{$\operatorname{Mari}^{7}$} \\
\hline & & NW & $\mathrm{CE}$ & SW & $\mathrm{E}$ & Total & & & & & & & & & & \\
\hline $\mathrm{DE}$ & M145/YAP & 3.5 & 0 & 3.0 & 1.7 & 1.9 & 1.2 & 0.2 & 5.0 & 3.4 & 8.2 & 2.9 & 6.6 & 2.5 & 0.4 & 0 \\
\hline $\mathrm{F}^{*}$ & $\begin{array}{l}\text { M89 (x G, } \\
\text { H, I, J, K) }\end{array}$ & 0 & 0 & 0 & 1.7 & 0.6 & 1.8 & 0.8 & 0.8 & 0.4 & 4.8 & 0 & 0 & 0.8 & 0.4 & 0 \\
\hline G & M201 & 0 & 0 & 0 & 1.7 & 0.6 & 0 & 1.2 & 0 & 1.4 & 0 & 1.5 & 2.5 & 0 & 0 & 0 \\
\hline I (total) & M170 & 13.8 & 10.3 & 3.0 & 10.3 & 9.4 & 11.6 & 13.1 & 17.5 & 23.4 & 28.8 & 17.1 & 21.0 & 16.9 & 28.9 & 8.1 \\
\hline $\mathrm{I}^{*}$ & $\begin{array}{l}\text { M170 (xI1, } \\
\text { I2a, I2b) }\end{array}$ & 0 & 0 & 0 & 0 & 0 & 0 & 0.8 & 0.6 & 0 & nda & 0 & 0 & 0 & 0 & nda \\
\hline I1 & M253 & 13.8 & 7.7 & 3.0 & 3.5 & 6.3 & 4.9 & 6.2 & 5.3 & 5.0 & nda & 10.0 & 14.8 & 11.9 & 28.0 & nda \\
\hline $\mathrm{I} 2 \mathrm{a}$ & P37 & 0 & 0 & 0 & 1.7 & 0.6 & 4.9 & 5.7 & 10.0 & 17.2 & nda & 5.4 & 3.0 & 4.2 & 0.2 & nda \\
\hline $\mathrm{I} 2 \mathrm{~b}$ & M223 & 0 & 2.6 & 0 & 5.1 & 2.5 & 1.8 & 0.4 & 1.6 & 1.2 & nda & 1.7 & 3.2 & 0.8 & 0.7 & nda \\
\hline $\mathrm{R}^{*}$ & $\begin{array}{c}\text { M207 } \\
\text { (xR1a, R1b, } \\
\text { R2) }\end{array}$ & 0 & 0 & 0 & 0 & 0 & 0 & 0 & 0 & 0.2 & 0 & 0 & 0 & 0 & 0.2 & 0 \\
\hline R1a & SRY1532. & 44.8 & 38.5 & 39.4 & 32.8 & 37.7 & 34.1 & 34.2 & 46.5 & 50.6 & 44.5 & 60.6 & 26.5 & 37.3 & 7.1 & 47.7 \\
\hline $\mathrm{R} 1 \mathrm{~b}$ & M343 & 6.9 & 7.7 & 15.2 & 3.5 & 7.6 & 4.9 & 5.4 & 7.5 & 6.0 & 8.2 & 11.9 & 36.7 & 4.2 & 3.7 & 2.7 \\
\hline Q & M242 & 0 & 0 & 3.0 & 0 & 0.6 & 0 & 0.7 & 0.3 & 0.2 & 0.2 & 0.6 & 0.2 & 0.8 & 0.2 & 0 \\
\hline $\mathrm{N}^{*}$ & $\begin{array}{c}\text { M231 (xN3, } \\
\text { N2a) }\end{array}$ & 0 & 0 & 0 & 0 & 0 & 0 & 0 & 0.4 & 0 & 0 & 0 & 0 & 0 & 0.2 & 0 \\
\hline $\begin{array}{l}\mathrm{N} 2 \mathrm{a} \\
\text { (prev. } \\
\mathrm{N} 1 \mathrm{~b})\end{array}$ & $\mathrm{P} 43$ & 0 & 0 & 0 & 0 & 0 & 0 & 7.5 & 0.5 & 0.5 & 0 & 0 & 0 & 0 & 0.4 & 9.9 \\
\hline $\begin{array}{l}\text { N3 (prev. } \\
\text { N1c) }\end{array}$ & M46/Tat & 31.0 & 43.6 & 36.4 & 48.3 & 41.5 & 43.9 & 35.5 & 16.3 & 9.6 & 0 & 3.1 & 1.1 & 33.9 & 58.2 & 31.5 \\
\hline $\mathrm{J}$ & M304 & 0 & 0 & 0 & 0 & 0 & 1.8 & 1.8 & 3.4 & 3.9 & 3.4 & 2.3 & 5.1 & 1.7 & 0 & 0 \\
\hline $\mathrm{K}^{*}$ & $\begin{array}{l}\text { M9 (xN, P, } \\
\text { R, T, O, L) }\end{array}$ & 0 & 0 & 0 & 0 & 0 & 0 & 0 & 1.7 & 0 & 2.1 & 0 & 0 & 0.8 & 0 & 0 \\
\hline $\mathrm{P}^{*}$ & P295 (Q, R) & 0 & 0 & 0 & 0 & 0 & 0.6 & 0 & 0 & 0 & 0 & 0 & 0 & 0.8 & 0 & 0 \\
\hline $\mathrm{Y}^{*}$ & $\begin{array}{l}\text { SRY10831a } \\
\text { (xA,B,C,D, } \\
\text { E,F,P) }\end{array}$ & 0 & 0 & 0 & 0 & 0 & 0 & 0 & 0 & 0 & 0 & 0 & 0 & 0 & 0.2 & 0 \\
\hline $\mathrm{C}$ & M130 & 0 & 0 & 0 & 0 & 0 & 0 & 0 & 0.2 & 0 & 0 & 0 & 0.2 & 0 & 0.2 & 0 \\
\hline $\mathrm{T}$ & M70 & 0 & 0 & 0 & 0 & 0 & 0 & 0 & 0 & 0.5 & 0 & 0 & 0.6 & 0 & 0 & 0 \\
\hline $\mathrm{n}$ & & 29 & 39 & 33 & 58 & 159 & 164 & 380 & 364 & 565 & 146 & 520 & 472 & 118 & 536 & 111 \\
\hline
\end{tabular}

${ }_{1}^{1}$ Pliss et al., 2015; ${ }^{2}$ Lappalainen et al., 2008; ${ }^{3}$ Balanovsky et al., 2008; ${ }^{4}$ Kushniarevich et al., $2013 ;{ }^{5}$ Mielnik-Sikorska et al., $2013 ;{ }^{6}$ Rebala et al., 2012;

${ }^{7}$ Tambets et al., 2004

ans and Lithuanians, lie in the vicinity of Finno-Ugric speaking Estonians according to their Y-chromosome diversity. It is also worth mentioning that the population genetic analysis on samples from North-Western Russia indicated a discrepancy in the depth of penetration of mtDNA and Ychromosome lineages characteristic for the majority of South-Western Russian populations in the east and north of Eastern Europe (Malyarchuk et al., 2004). These results led the authors to conclude that Russian colonisation of northeastern European territories might have been accomplished mainly by males rather than by females.

The most detailed analysis of NRY in Latvians was performed by Pliss et al. (2015), who investigated 159 unrelated ethnic Latvian males from the above-mentioned four different geographic regions, using 28 biallelic markers and 12 STRs (Pliss et al., 2015). Eleven different haplogroups (hgs) (Table 9) and 130 distinctive haplotypes were detected in a regionally relatively homogeneous Latvian population. The vast majority of the analysed samples belonged to two predominant hgs, $\mathrm{N} 3$ (formerly $\mathrm{N} 1 \mathrm{c}$ ) and R1a (41.5\% and $37.7 \%$, accordingly). Twelve samples (7.6\%) represented hg R1b, which is carried predominantly by Western Europeans (Eastern Europeans, in contrast, have high frequency of R1a lineages). The next abundant variant among Latvians was hg I1 with a frequency of $6.3 \%$. Another two phylogenetic branches of hg I occur at a low level in Latvians: hg I2b was found at a frequency of $2.5 \%$ and hg I2a comprised only $0.6 \%$. In general, the gene pool of the Latvian Y-chromosomes was characterised by the pres- 

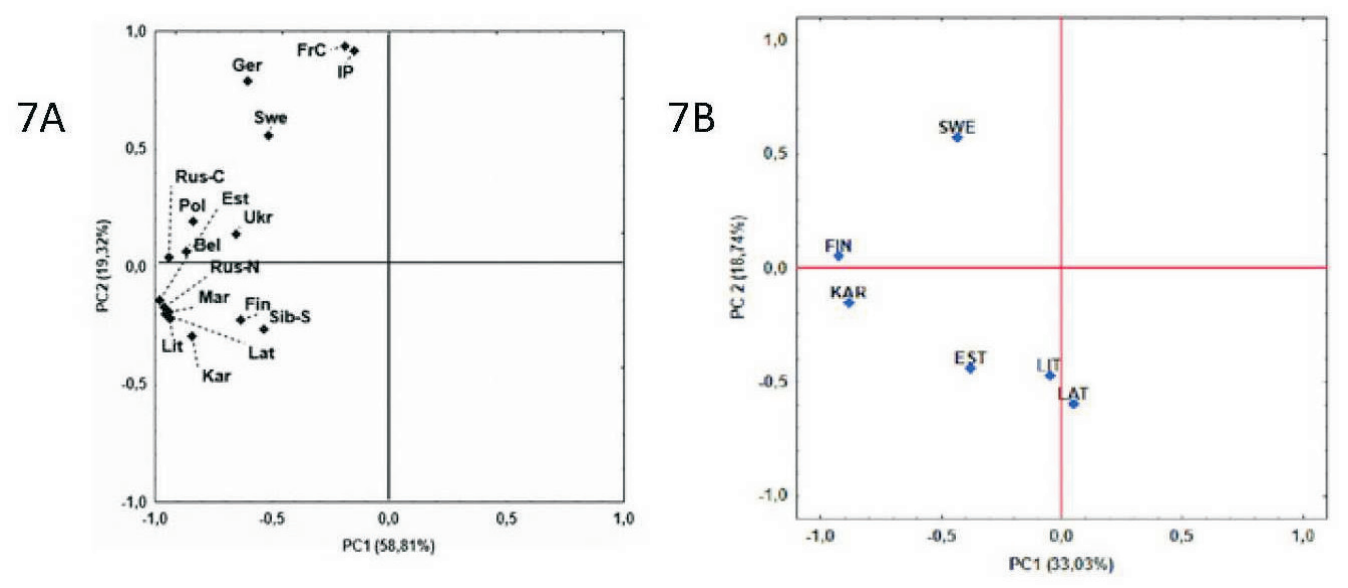

Fig. 7. Comparison of Latvian population with other populations based on variation of the Y-chromosomal haplogroups (7A) and compound haplotypes (7B) (Pliss et al., 2015). 7A, population codes are given in alphabetical order as follows: Bel, Belarusians; Est, Estonians; Fin, Finns; FrC, French and Corsicans; Ger, Germans; IB, Iberian Peninsula’s populations; Kar, Karelians; Lat, Latvians; Lit, Lithuanians; Mar, Maris; Pol, Poles; Rus N/C, Russians Northern/Central; Sib-S, South Siberians; Swe, Swedes; Ukr, Ukrainians. PC1 and PC2, principal component 1 and 2 are significant.

7B, population codes are given in alphabetical order as follows: EST, Estonians; FIN, Finns; KAR, Karelians; LAT, Latvians; LIT, Lithuanians; SWE, Swedes. PC1 and PC2, principal component 1 and 2 are significant.

ence of the majority of hgs typical to Eastern and Northern Europe, and only one sample fell into hg Q $(0.6 \%)$, which is more characteristic to Asian populations, but is occasionally also found in Europe (Tambets et al., 2004; Balanovsky et al., 2008; Lappalainen et al., 2008). Statistically significant differences in the distribution of hgs between the sampled Latvian subpopulations were not found. Results of principal component analysis (PCA) performed on the distribution of hgs among 16 populations revealed that the Latvian population formed a tight cluster with the North-European populations, irrespective of linguistic affiliation, that is, with Estonians, Maris, Northern Russians, and Lithuanians, all having a high frequency of N3 (Fig. 7A). For the analysis of compound haplotypes, nine YSTRs were used, and only six European populations were included due to the absence of a comparable set of Y-STR data in other neighbouring populations. Results of PCA grouped Baltic-speaking Latvians and Lithuanians together and lightly split them from FinnoUgric-speaking Estonians (Fig. 7B). Such an observation could be explained by different haplotype composition of the most abundant Y-chromosomal lineages, namely, N3 and R1a, in those populations. The majority of haplotypes (24) shared between Latvians and neighbouring populations were found for hg R1a. Only four compound haplotypes were in common within hg N3. Despite the comparable frequency distribution of hg N3 in Latvians and Lithuanians with the Finno-Ugric-speaking populations from the eastern coast of the Baltic Sea, the observed differences in allelic variances of N3 haplotypes between these two groups are in concordance with the previously stated hypothesis (Zerjal et al., 2001; Kasperavičiūte et al., 2004; Lappalainen et al., 2008) of two migration waves that introduced hg N3 founder haplotypes to the eastern coast of the Baltic Sea: "Baltic" — in the south of the Baltic Sea through the Baltic countries to Poland and Germany; and "Fennoscandian" in the north of the Baltic Sea through Finland to Sweden. It was suggested that $\mathrm{N} 3$ chromosomes originated in Asia and were brought to Europe by Finno-Ugric speakers prior to the arrival of Indo-European speakers. Recently performed high-coverage $\mathrm{Y}$ chromosome sequencing (a method that allows to identify previously undetected lineages) from 56 Eurasian populations, including two Latvian samples, showed that both Latvian samples belong to haplogroup N3, clade N3a3-VL29 (Karmin et al., 2015; Ilumäe et al., 2016). This clade is found in over a third of the present-day male Estonians, Latvians, and Lithuanians, and it is present also among Finns, Karelians, Saami. It was suggested that the distribution of this $\mathrm{Y}$ chromosome lineage has been shaped by random genetic drift in small populations dispersed across a wide area (Ilumäe et al., 2016).

Hg R1a is frequent in North-Eastern Europe, with the highest frequencies $(30 \%-50 \%)$ in Slavic-speaking populations and moderate among populations of Volga-Ural basin. Recently, Underhill et al. (2015) underwent a detailed phylogeographic study of European-specific R1a sub-clades of R1a-M458 and R1a-M558 lineages. R1a-M458 shows the highest distribution among European frequencies (exceeding 30\%) in Central and Eastern Europe (Underhill et al., 2010). The highest frequency of R1a-M458 was found in Poles, Czechs, Slovaks, and Western Belarusians (20\%). Unlike R1a-M458, the R1a-M558 lineage is more common in Eastern Slavs and in Volga-Uralic populations. R1aM558 is found in various parts of Russia (10\%-30\%), as well as in Poland and Western Belarus where it transcends $26 \%$, and in Ukraine, where its frequency varies between $10 \%$ and $23 \%$, whereas it occurs at significantly lower frequencies in Western Europe (Underhill et al., 2015). The study of R1a Y-chromosomes in the Latvian sample performed by Pliss et al. (2015) showed that the R1a-M458 lineage was found at a relatively low frequency, as opposed to the R1a-M558 lineage, which accounts for nearly all R1a hg representatives and more than a third of all Latvian paternal lineages. The authors suggested that high prevalence 
of R1a-M558 in Latvians and their haplotypes shared with Eastern Slavic-speaking populations may indicate a shared genetic ancestry component or a possible more recent gene flow from Eastern Slavic-speaking populations to presentday Latvians. There were many R1a-M558 haplotypes in Latvians that were detected also among Eastern Slavicspeaking Russians, Ukrainians, and Belarusians (Underhill et al., 2015).

Recent analysis of fourteen Mesolithic and Neolithic ancient male DNA samples from the archaeological site of Zvejnieki in Northern Latvia showed haplogroups R1b (eight samples), I2a (five samples) and Q (one sample) (Table 1; Jones et al., 2017; Mathieson et al., 2017). R1b, the most common hg found in modern Western Europeans, has been found at low frequencies before the Late Neolithic in Western Europe but at higher frequencies in Russia. It was suggested that this hg spread into Western Europe from the East after 5000 cal YBP (Haak et al., 2015). Haplogroup I2a has been commonly found among Western huntergatherers (Lazaridis et al., 2014). The analysis of six Bronze Age individuals from Kivutkalns burial revealed haplogroups R1a (five individuals) and R1b (one individual) (Mittnik et al., 2017a, b). No cases of haplogroup N, which is a very common $\mathrm{Y}$ chromosome haplogroup in modern Latvians (41.5\%), Lithuanians, Finns and Estonians (Ilumäe et al., 2016) were detected among Latvian ancient DNA samples. It is proposed that this haplogroup was brought to the Eastern Baltic after the Late Bronze Age (Mittnik et al., 2017a).

\section{CONCLUSIONS}

Population genetic studies of Latvians, which represent one of the two extant Baltic-speaking populations besides Lithuanians, have shown a mixture of genetic traits typical for Western Europe and Eastern Eurasia with only small differences between Latvian subpopulations.

The analyses of genome-wide single nucleotide polymorphisms have shown that Latvians and Lithuanians clustered in close proximity to Russians from the central part of European Russia and Estonians, although Estonians had a higher proportion of ancestry component common with Finns.

The studies of the Baltic "tribal gene" $\mathrm{LW}^{\mathrm{b}}$ as well as gene's SERPINA1 allele PIZ indicate the presence of a considerable Baltic admixture in the neighbouring Finno-Ugric and Slavic populations.

The analyses of mitochondrial DNA have shown that in general Latvians belong to the same common gene pool as most Europeans, with Latvians and Lithuanians forming a tight cluster with Estonians, Russians, Belarusians, and Poles. The vast majority of mtDNA HVS-I haplotypes found among Latvians are identical to or close derivatives of those observed in other Eastern and Western European populations, irrespective of their linguistic affiliations.
The analyses of Y-chromosome lineages, contrary to mtDNA data, have revealed deeper differences between North-European populations, with Lithuanians, Estonians, and Eastern-Slavic populations being ethnogenetically closest to Latvians.

Studies of ancient DNA samples from the territory of today's Latvia have shown some hunter-gatherer ancestry persistence across the Neolithic transition, impact from Northern Eurasian populations between the Early Neolithic and the Middle Neolithic as well as impact from the Pontic Steppe populations during the Late Neolithic and Bronze Age. There are no signs of Anatolian farmer-related genetic input on the population of Latvia at least until the end of the Bronze Age. Further research of ancient DNA samples from different archaeological cultures with comparison to present-day populations with detailed joint analysis of genetic, craniometric, archaeological, and linguistic data is needed to reveal demographic events that created present-day Latvian genetic diversity.

\section{ACKNOWLEDGEMENTS}

The authors are grateful to Prof. Elmārs Grēns (Latvian Biomedical Research and Study Centre) for support and encouragement, Prof. Andrejs Vasks (Institute of Latvian History, University of Latvia) and Jānis Ciglis (National History Museum of Latvia) for helpful information on the history of Latvia; to all individuals who donated their genomic material for the studies.

\section{REFERENCES}

Ajioka, R. S., Jorde, L. B., Gruen, J. R., Yu, P., Dimitrova, D., Barrow, J., Radisky, E., Edwards, C. Q., Griffen, L. M., Kushner, J. P. (1997). Haplotype analysis of hemochromatosis: Evaluation of different linkage-disequilibrium approaches and evolution of disease chromosomes. Amer. J. Hum. Genet., 60, 1439-1447.

Allentoft, M. E., Sikora, M., Sjögren, K.-G., Rasmussen, S., Rasmussen, M., Stenderup, J., Damgaard, P. B., Schroeder, H., Ahlström, T., Vinner, L., Malaspinas, A.-P., Margaryan, A., Higham, T., Chivall, D., Lynnerup, N., Harvig, L., Baron, J., Casa, P. D., Dąbrowski, P., Duffy, P. R., Ebel, A. V., Epimakhov, A., Frei, K., Furmanek, M., Gralak, T., Gromov, A., Gronkiewicz, S., Grupe, G., Hajdu, T., Jarysz, R., Khartanovich, V., Khokhlov, A., Kiss, V., Kolių, J., Kriiska, A., Lasak, I., Longhi, C., McGlynn, G., Merkevicius, A., Merkyte, I., Metspalu, M., Mkrtchyan, R., Moiseyev, V., Paja, L., Pịlfi, G., Pokutta, D., Pospieszny, L., Price, T. D., Saag, L., Sablin, M., Shishlina, N., Vịclav Smrčka, V., Soenov, V. I., Szeverényi, V., Tóth, G., Trifanova, S. V., Varul, L., Vicze, M., Yepiskoposyan, L., Zhitenev, V., Orlando, L., Sicheritz-Pontén, T., Brunak, S., Nielsen, R., Kristiansen, K., Eske Willerslev, E. (2015). Population genomics of Bronze Age Eurasia. Nature, 522, 167-172.

Balanovsky, O., Pocheshkhova, E., Pshenichnov, A., Solovieva, D., Kuznetsova, M., Voronko, O., Churnosov, M., Tegako, O., Atramentova, L., Lavryashina, M., Evseeva, I., Borinska, S., Boldyreva, M., Dubova, N., Balanovska, E. (2005). Is spatial distribution of the HIV-resistant CCR5 32 allele formed by ecological factors? J. Physiol. Anthropol. Appl. Hum. Sci., 24, 375-382.

Balanovsky, O., Rootsi, S., Pshenichnov, A., Kivisild, T., Churnosov, M., Evseeva, I., Pocheshkhova, E., Boldyreva, M., Yankovsky, N., Balanovska, E., Villems, R. (2008). Two sources of the Russian patilineal heritage in their Eurasian context. Amer. J. Hum. Genet., 82, 236-250. 
Beckman, L., Sikstrom, C., Mikelsaar, A.-V., Krumina, A., Kučinskas, V., Beckman, G. (1999). $\alpha_{1}$-antitrypsin (PI) alleles as markers of Westeuropean influence in the Baltic Sea region. Human Heredity, 49, 52-55.

Bergholdt, H. K. M., Nordestgaard, B. G., Varbo, A., Ellervik, C. (2015). Milk intake is not associated with ischaemic heart disease in observational or Mendelian randomization analyses in 98529 Danish adults. Int. J. Epidem., 44 (2), 587-603.

Bermisheva, M., Tambets, K., Villems, R., Khusnutdinova, E. (2002). Diversity of mitochondrial DNA haplotypes in ethnic populations of the Volga-Ural region of Russia. Mol. Biol. (Moscow), 36, 802-812.

Bersaglieri, T., Sabeti, P. C., Patterson, N., Vanderploeg, T., Schaffner, S. F., Drake, J. A., Rhodes, M., Reich, D. E., Hirschhorn, J. N. (2004). Genetic signatures of strong recent positive selection at the lactase gene. Amer. J. Hum. Genet., 74, 1111-1120.

Bērziņš, V., Vasks, A. (2013). Latvijas aizvēsture (līdz 800. gadam) [Prehistory of Latvia (until 800)]. In: Stradiňš, J. (Ed.). Latvieši un Latvija [Latvians and Latvia], I sēj. Latvieši [Latvians]. LZA, Rīga, pp. 51-83 (in Latvian).

Blanco, I., de Serres, F.J., Fernandes-Bustillo, E., Lara, B., Miravitlles, M. (2006). Estimated numbers and prevalence of PI S and PI Z alleles of $\alpha_{1}-$ antitrypsin deficiency in European countries. Eur. Respir. J., 27, 77-84.

Bouckaert, R., Lemey, P., Dunn, M., Greenhill, S. J., Alekseyenko, A. V., Drummond, A. J., Gray, R. D., Suchard, M. A., Atkinson, Q. D. (2012). Mapping the origins and expansion of the Indo-European language family. Science, 337, 957-960.

Brandt, G., Haak, W., Adler, C. J., Roth, C., Szėcsényi-Nagy, A., Karimnia, S., Möller-Rieker, S., Meller, H., Ganslmeier, R., Friederich, S., Dresely, V., Nicklisch, N., Pickrell, J. K., Sirocko, F., Reich, D., Cooper, A., Alt, K.W., Genographic Consortium. (2013). Ancient DNA reveals key stages in the formation of central European mitochondrial genetic diversity. Science, 342, 257-261.

Burger, J., Kirchner, M., Bramanti, B., Haak, W., Thomas, M.G. (2007). Absence of the lactase-persistence-associated allele in early Neolithic Europeans. Proc. Natl. Acad. Sci. USA, 104, 3736-3741.

Byrne, K. M., Byrne, P. C. (2004). Review: Other blood group systems Diego, Yt, Xg, Scianna, Dombrock, Colton, Landsteiner-Wiener, and Indian. Immunohematology, 20, 50-58.

Carroll, T. P., O`Connor, C. A., Floyd, O., McPartlin, J., Kelleher, D. P., O`Brien, G., Dimitrov, B. D., Morris, V. B., Taggart, C. C., McElvaney, N. G. (2011). The prevalence of alpha-1 antitrypsin deficiency in Ireland. Resp. Res., 12, 91-98.

Cauna, N. (1942). Par latviešu asins grupām [On Latvian blood groups]. Ärstniecības žurnāls, Nr. 1, 254-260 (in Latvian).

Cook, C. J. (2014). The role of lactase persistence in precolonial development. J. Econ. Growth, 19, 369-406.

Česnys, G. (1991). Anthropological roots of Lithuanians. Science, Arts Lith., 1, 4-10.

Davydenko, O. G., Kushniarevich, A. I., Sivitskaya, L. N., Danilenko, N. G. (2007). Ethnogenomics of Belarusians. Preliminary results [Давыденко, О. Г., Кушнеревич, Е. И., Сивицкая, Л. Н., Даниленко, Н. Г. Этногеномика белорусского народа. Предварительные итоги]. Molecular Appl. Gen. [Молекулярная и прикладная генетика], 6, 45-78 (in Russian)

de Juan, D., Reta, A., Castiella, A., Pozueta, J., Prada, A., Cuadrado, E. (2001). HFE gene mutations analysis in Basque hereditary haemochromatosis patients and controls. Eur. J. Hum. Genet., 9, 961-964.

Denisova, R. (1975). Anthropology of Ancient Balts [Денисова, Р. А. Антропология древних балтов]. Zinātne, Rīga. 400 pp. (in Russian).

Denisova, R. (1997). Latvijas senākā apdzīvotība [The initial settlement of Latvia]. J. Latv. Hist. Inst., No. 3, 5-15 (in Latvian). de Silva, E., Stumpf, M. P. H. (2004). HIV and the CCR5-Delta32 resistance allele. FEMS Microbiol. Lett., 241, 1-12.

Distante, S., Robson, K. J., Graham-Campbell, J., Arnaiz-Villena, A., Brissot, P., Worwood, M. (2004). The origin and spread of the HFEC282Y haemochromatosis mutation. Hum. Genet., 115, 269-279.

Enattah, N. S., Sahi, T., Savilahti, E., Terwilliger, J. D., Peltonen, L., Järvelä, I. (2002). Identification of a variant associated with adult-type hypolactasia. Nat. Genet., 30, 233-237.

Farrell, P. M. (2008). The prevalence of cystic fibrosis in the European Union. J. Cystic Fibr., 7, 450-453.

Faure, E., Royer-Carenzi, M. (2008). Is the European spatial distribution of the HIV-resistant CCR5- $\triangle 32$ allele formed by a breakdown of the pathocenosis due to the historical Roman expansion? Infect. Genet. Evol., 8, 864-874.

Galvani, A. P., Novembre, J. (2005). The evolutionary history of the CCR5-Delta32 HIV-resistance mutation. Microbes Infect., 7, 302-309.

Galvani, A. P., Slatkin, M. (2003). Evaluating plague and smallpox as historical selective pressures for the CCR5-delta 32 HIV-resistance allele. Proc. Natl. Acad. Sci. USA, 100, 15276-15279.

Gimbutiene (Gimbutas), M. (1994). Balti aizvēsturiskajos laikos [Balts in prehistoric times]. Zinātne, Rīga. 226 pp. (in Latvian).

Gray, R. D., Atkinson, Q. D. (2003). Language-tree divergence times support the Anatolian theory of Indo-European origin. Nature, 426, 435-439.

Haak, W., Lazaridis, I., Patterson, N., Rohland, N., Mallick, S., Llamas, B., Brandt, G., Nordenfelt, S., Harney, E., Stewardson, K., Fu, Q., Mittnik, A., Binffy, E., Economou, C., Francken, M., Friederich, S., Pena, R. G., Hallgren, F., Khartanovich, V., Khokhlov, A., Kunst, M., Kuznetsov, P., Meller, H., Mochalov, O., Moiseyev, V., Nicklisch, N., Pichler, S. L., Risch, R., Rojo Guerra, M. A., Roth, C., Szécsényi-Nagy, A., Wahl, J., Meyer, M., Krause, J., Brown, D., Anthony, D., Cooper, A., Alt, K. W., Reich, D. (2015). Massive migration from the steppe was a source for Indo-European languages in Europe. Nature, 522 (7555), 207-211.

Hakulinen, L. (1961). The Structure and Development of the Finnish Language. Curzon. 383 pp.

Hummel, S., Schmidt, D., Kremeyer, B., Herrmann, B., Oppermann, M. (2005). Detection of the CCR5-Delta32 HIV resistance gene in Bronze Age skeletons. Genes Immun., 6, 371-374.

Hutchison, D. C. (1998). Alpha-1-antitrypsin deficiency in Europe: Geographical distribution of Pi types S and Z. Resp. Med., 92, 367-377.

Ilumäe, A.-M., Reidla, M., Chukhryaeva, M., Järve, M., Post, H., Karmin, M., Saag, L., Agdzhoyan, A., Kushniarevich, A., Litvinov, S., Ekomasova, N., Tambets, K., Metspalu, E., Khusainova, R., Yunusbayev, B., Khusnutdinova, E. K., Osipova, L. P., Fedorova, S., Utevska, O., Koshel, S., Balanovska, E., Behar, D. M., Balanovsky, O., Kivisild, T., Underhill, P. A., Villems, R., Rootsi, S. (2016). Human Y chromosome haplogroup N: A non-trivial time-resolved phylogeography that cuts across language families. Amer. J. Hum. Genet., 99, 163-173.

Itan, Y., Powell, A., Beaumont, M. A., Burger, J., Thomas, M. G. (2009). The origins of lactase persistence in Europe. PloS Computational Biology, 5, e1000491.

Ivanova, A., von Ahsen, N., Adjarov, D., Krastev, Z., Oellerich, M., Wieland, E. (1999). C282Y and H63D mutations in the HFE gene are not associated with porphyria cutanea tarda in Bulgaria. Hepatology, 30, 1531-1532.

Jones, E. R., Zarina, G., Moiseyev, V., Lightfoot, E., Nigst, P. R., Manica, A., Pinhasi, R., Bradley, D. G. (2017). The Neolithic transition in the Baltic was not driven by admixture with early European farmers. Curr. Biol., 27, $576-582$.

Kalibatiene, D., Varvuolyte, S., Alekna, V. (2006). Investigation of hypolactasia in the elderly. Gerontologija, 7, 136-142. 
Karmin, M., Saag, L., Vicente, M., Wilson Sayres, M. A., Järve, M., Talas, U. G., Rootsi, S., Ilumäe, A.-M., Mägi, R., Mitt, M., Pagani, L., Puurand, T., Faltyskova, Z., Clemente, F., Cardona, A., Metspalu, E., Sahakyan, H., Yunusbayev, B., Hudjashov, G., DeGiorgio, M., Loogväli, E.-L., Eichstaedt, C., Eelmets, M., Chaubey, G., Tambets, K., Litvinov, S., Mormina, M., Xue, Y., Ayub, Q., Zoraqi, G., Korneliussen, T. S., Akhatova, F., Lachance, J., Tishkoff, S., Momynaliev, K., Ricaut, F.-X., Kusuma, P., Razafindrazaka, H., Pierron, D., Cox, M. P., Sultana, G. N. N., Willerslev, R., Muller, C., Westaway, M., Lambert, D., Skaro, V., Kovačevic', L., Turdikulova, S., Dalimova, D., Khusainova, R., Trofimova, N., Akhmetova, V., Khidiyatova, I., Lichman, D. V., Isakova, J., Pocheshkhova, E., Sabitov, Z., Barashkov, N. A., Nymadawa, P., Mihailov, E., Seng, J. W. T., Evseeva, I., Migliano, A. B., Abdullah, S., Andriadze, G., Primorac, D., Atramentova, L., Utevska, O., Yepiskoposyan, L., Marjanovic', D., Kushniarevich, A.,. Behar, D. M., Gilissen, C., Vissers, L., Veltman, J. A., Balanovska, E., Derenko, M., Malyarchuk, B., Metspalu, A., Fedorova, S., Eriksson, A., Manica, A., Mendez, F. L., Karafet, T. M., Veeramah, K. R., Bradman, N., Hammer, M. F., Osipova, L. P., Balanovsky, O., Khusnutdinova, E. K., Johnsen, K., Remm, M., Thomas, M. G., Tyler-Smith, C., Underhill, P. A., Willerslev, E., Nielsen, R., Metspalu, M., Villems, R., Kivisild, T. (2015). A recent bottleneck of $\mathrm{Y}$ chromosome diversity coincides with a global change in culture. Genome Res., 25, 459-466.

Kasperavičiute, D., Kučinskas, V., Stoneking, M. (2004). Y-chromosome and mitochondrial DNA variation in Lithuanians. Ann. Hum. Genet., 68, $438-452$.

Khrunin, A. V., Khokhrin, D. V., Filippova, I. N., Esko, T., Nelis, M., Bebyakova, N. A., Bolotova, N. L., Klovins, J., Nikitina-Zake, L., Rehnström, K., Ripattii, S., Schreiber, S., Franke, A., Macek, M., Krulišová, V., Lubinski, J., Metspalu, A., Limborska, S. A. (2013). A genome-wide analysis of populations from European Russia reveals a new pole of genetic diversity in northern Europe. PLOS ONE, 8, e58552.

Klitz, W., Brautbar, C., Schito, A. M., Barcellos, L. F., Oksenberg, J. R. (2001). Evolution of the CCR5 delta 32 mutation based on haplotype variation in Jewish and Northern European population samples. Hum. Immunol., 62, 530-538.

Krūmiņa, A., Kroškina, V., Keišs, J., Mališeva, B., Baumanis, V. (2001a). Ar hereditāro hemohromatozi saistītās gēna HFE mutācijas Latvijas populācijā [Hereditary haemochromatosis related HFE gene mutations in Latvian population]. In: Scientific Proceedings of Riga Stradinš University. RSU, Rīga, pp. 134-138 (in Latvian)

Krumina, A., Kroshkina, V., Krumina, L., Svabe, V., Krumina, Z., Tamane, I., Baumanis, V. (2001b). Cystic fibrosis mutation dF508 in the Latvian population. Scientific Proceedings of Riga Stradinš University. RSU, Rīga, pp. 161-166.

Krūmiņa, A., Kroškina, V., Švābe, V., Krūmiņa, Z., Lazdiņš, M., Baumanis, V. (2000). Mukoviscidozi izraisošo mutāciju spektrs Latvijā [Cystic fibrosis mutation spectrum in Latvia]. Scientific Proceedings of Riga Stradiňš University. RSU, Rīga, pp. 102-105 (in Latvian).

Kucinskas, L., Juzenas, S., Sventoraityte, R., Cedaviciute, R., Vitkauskiene, A., Kalibatas, V., Kondrackiene, J., Kupcinskas, L. (2012). Prevalence of $\mathrm{C} 282 \mathrm{Y}, \mathrm{H} 63 \mathrm{D}$, and S65C mutations in hereditary HFE-hemochromatosis gene in Lithuanian population. Ann. Hematol., 91, 491-495.

Kučinskas, V. (2001). Population genetics of Lithuanians. Ann. Hum. Biol., 28, 1-14.

Kučinskas, V., Sistonen, P., Beckman, L. (1998). The LW (Landsteiner Wiener) blood group system phenotypes and $\mathrm{LWb}$ allele frequencies in six Lithuanian ethnolinguistic subgroups. Acta Medica Lituanica, 4, 281-283.

Kushniarevich, A., Sivitskaya, L., Danilenko, N., Novogrodskii, T., Tsybovsky, I., Kiseleva, A., Kotova, S., Chaubey, G., Metspalu, E., Sahakyan, H., Bahmanimehr, A., Reidla, M., Rootsi, S., Parik, J., Reisberg, T., Achilli, A., Kashani, B. H., Gandini, F., Olivieri, A., Behar, D. M., Torroni, A., Davydenko, O., Villems, R. (2013). Uniparental genetic heritage of Belarusians: Encounter of rare Middle Eastern matrilineages with a Central European mitochondrial DNA pool. PloS ONE, 8 (6), e66499.
Kushniarevich, A., Utevska, O., Chuhryaeva, M., Agdzhoyan, A., Dibirova, K., Uktveryte, I., Möls, M., Mulahasanovic, L., Pshenichnov, A., Frolova, S., Shanko, A., Metspalu, E., Reidla, M., Tambets, K., Tamm, E., Koshel, S., Zaporozhchenko, V., Atramentova, L., Kučinskas, V., Davidenko, O., Goncharova, O., Evseeva, I., Chumosov, M., Pocheshchova, E., Yunusbayev, B., Khnusnutdinova, E., Marjanović, D., Rudan, P., Rootsi, S., Yankovsky, N., Endicott, P., Kassian, A., Dybo, A., The genographic Consortium, Tyler-Smith, C., Balanovska, E., Metspalu, M., Kivisild, T., Villems, R., Balanovsky, O. (2015). Genetic heritage of the Balto-Slavic speaking populations: A synthesis of autosomal, mitochondrial and Y-chromosomal data. PloS ONE, 10 (9), e0135820.

Lace, B., Sveger, T., Krams, A., Cernevska, G., Krumina, A. (2008). Age of SERPINA1 gene PI Z mutation: Swedish and Latvian population analysis. Ann. Hum. Genet., 72, 300-304.

Laitinen, V., Lahermo, P., Sistonen, P., Savontaus, M.-L. (2002). $\mathrm{Y}$-chromosomal diversity suggests that Baltic males share common Finno-Ugric-speaking forefathers. Hum. Hered., 53, 68-78.

Laland, K. N., Odling-Smee, J., Myles, S. (2010). How culture shaped the human genome: Bringing genetics and the human sciences together. Nat. Rev. Genet., 11, 137-148.

Lappalainen, T., Laitinen, V., Salmela, E., Andersen, P., Huoponen, K., Savontaus, M.-L., Lahermo, P. (2008). Migration waves to the Baltic Sea region. Ann. Hum. Genet., 72, 337-348

Lazaridis, I., Patterson, N., Mittnik, A., Renaud, G., Mallick, S., Kirsanow, K., Sudmant, P. H., Schraiber, J. G., Castellano, S., Lipson, M., Berger, B., Economou, C., Bollongino, R., Fu, Q., Bos, K. I., Nordenfelt, S., Li, H., de Filippo, C., Prüfer, K., Sawyer, S., Posth, C., Haak, W., Hallgren, F., Fornander, E., Rohland, N., Delsate, D., Francken, M., Guinet, J.-M., Wahl, J., Ayodo, G., Babiker, H. A., Bailliet, G., Balanovska, E., Balanovsky, O., Barrantes, R., Bedoya, G., Ben-Ami, H., Bene, J., Berrada, F., M. Bravi, C. M., Brisighelli, F., Busby, G. B. J., Cali, F., Churnosov, M., Cole, D. E. C., Corach, D., Damba, L., van Driem, G., Dryomov, S., Dugoujon, J.-M., Fedorova, S. A., Romero, I. G., Gubina, M., Hammer, M., Henn, B. M., Hervig, T., Hodoglugil, U., Jha, A. R., Karachanak-Yankova, S., Khusainova, R., Khusnutdinova, E., Kittles, R., Kivisild, T., Klitz, W., Kučinskas, V., Kushniarevich, A., Laredj, L., Litvinov, S., Loukidis, T., Mahley, R. W., Melegh, B., Metspalu, E., Molina, J., Mountain, J., Näkkäläjärvi, K., Nesheva, D., Nyambo, T., Osipova, L., Parik, J., Platonov, F., Posukh, O., Romano, V., Rothhammer, F., Rudan, I., Ruizbakiev, R., Sahakyan, H., Sajantila, A., Salas, A., Starikovskaya, E. B., Tarekegn, A., Toncheva, D., Turdikulova, S., Uktveryte, I., Utevska, O., Vasquez, R., Villena, M., Voevoda, M., Winkler, C., Yepiskoposyan, L., Zalloua, P., Zemunik, T., Cooper, A., Capelli, C., Thomas, M. G., Ruiz-Linares, A., Tishkoff, S. A., Singh, L., Thangaraj, K., Villems, R., Comas, D., Sukernik, R., Metspalu, M., Meyer, M., Eichler, E. E., Burger, J., Slatkin, M., Pääbo, S., Kelso, J., Reich, D., Krause, J. (2014). Ancient human genomes suggest three ancestral populations for present-day Europeans. Nature, 513, 409-413.

Lember, M., Torniainen, S., Kull, M., Kallikorm, R., Saadla, P., Rajasalu, T., Komu, H., Järvelä, I. (2006). Lactase non-persistence and milk consumption in Estonia. World J. Gastroenterol., 12, 7329-7331.

Lessig, R., Edelmann, J., Krawczak, M. (2001). Population genetics of Y-chromosomal microsatellites in Baltic males. Forensic Sci. Int., 118, 153-157.

Li, J. Z., Absher, D. M., Tang, H., Southwick, A. M., Casto, A. M., Ramachandran, S., Cann, H. M., Barsh, G. S., Feldman, M., Cavalli-Sforza, L. L., Myers R. M. (2008). Worldwide human relationships inferred from genome-wide patterns of variation. Science, $\mathbf{3 1 9}$, 1100-1104.

Libert, F., Cochaux, P., Beckman, G., Samson, M., Aksenova, M., Cao, A., Czeizel, A., Claustres, M., de la Rśa, C., Ferrari, M., Ferrec, C., Glover, G., Grinde, B., Güran, S., Kucinskas, V., Lavinha, J., Mercier, B., Ogur, G., Peltonen, L., Rosatelli, C., Schwartz, M., Spitsyn, V., Timar, L., Beckman, L., Parmentier, M., Vassart, G. (1998). The $\triangle$ CCR5 mutation conferring protection against HIV-1 in Caucasian populations has a single and recent origin in Northeastern Europe. Hum. Mol. Genet., 7, 399-406. 
Limborska, S. A., Balanovsky, O. P., Balanovskaya, E. V., Slominsky, P. A., Schadrina, M. I., Livshits, L. A., Kravchenko, S. A., Pampuha, V. M., Khusnutdinova, E. K., Spitsyn, V. A. (2002). Analysis of CCR5 432 geographic distribution and its correlation with some climatic and geographic factors. Hum. Hered., 53, 49-54.

Loogväli, E. L., Roostalu, U., Malyarchuk, B. A., Derenko, M. V., Kivisild, T., Metspalu, E., Tambets, K., Reidla, M., Tolk, H. V., Parik, J., Pennarun, E., Laos, S., Lunkina, A., Golubenko, M., Barac, L., Pericic, M., Balanovsky, O. P., Gusar, V., Khusnutdinova, E. K., Stepanov, V., Puzyrev, V., Rudan, P., Balanovska, E. V., Grechanina, E., Richard, C., Moisan, J. P., Chaventre, A., Anagnou, N. P., Pappa, K. I., Michalodimitrakis, E. N., Claustres, M., Golge, M., Mikerezi, I., Usanga, E., Villems, R. (2004). Disuniting uniformity: A pied cladistic canvas of mtDNA haplogroup H in Eurasia. Mol. Biol. Evol., 21, 2012-2021.

Madry, E., Krasinska, B., Walkowiak, J., Adamczak-Ratajczak, H. (2011). Hypolactasia, lactose malabsorption, lactose intolerance. Family Med. Primary Care Rev., 13, 334-336.

Mališeva, B., Tamane, I., Krūmiņa, L., Kroškina, V., Baumanis, V., Krūmiṇa, A. (2002). Alfa 1-antitripsīna nepietiekamības klīnika, diagnostika un izplatība Latvijā [Alpha 1-antitrypsin deficiency: Clinical symptoms, diagnostics and prevalence in Latvia]. Scientific Proceedings of Riga Stradiňš University. RSU, Rīga, pp. 167-171 (in Latvian).

Malmström, H., Gilbert, M. T. P., Thomas, M. G., Brandström, M., Storị, J., Molnar, P., Andersen, P. K., Bendixen, C., Holmlund, G., Götherström, A., Willerslev E. (2009). Ancient DNA reveals lack of continuity between neolithic hunter-gatherers and contemporary Scandinavians. Cuur. Biol., 19, $1758-1762$.

Malyarchuk, B., Derenko, M., Grzybowski, T., Lunkina, A., Czarny, J., Rychkov, S., Morozova, I., Denisova, G., Micicka-Sliwka, D. (2004). Differentiation of mitochondrial DNA and Y chromosomes in Russian populations. Hum. Biol., 76, 877-900.

Malyarchuk, B., Derenko, M., Grzybowski, T., Perkova, M., Rogalla, U., Vanecek, T., Tsybovsky, I. (2010). The peopling of Europe from the mitochondrial haplogroup U5 perspective. PloS ONE, 5, e10285.

Malyarchuk, B. A., Grzybowski, T., Derenko, M. V., Czarny, J., Wožniak, M., Miścicka-Śliwka, D. (2002). Mitochondrial DNA variability in Poles and Russians. Ann. Hum. Genet., 66, 261-283.

Mathieson, I., Roodenberg, S. A., Posth, C., Szécsényi-Nagy, A., Rohland, N., Mallick, S., Olade, I., Broomandkhoshbacht, N., Cheronet, O., Fernandes, D., Ferry, M., Gamarra, B., Fortes, G. G., Haak, W., Harney, E., Krause-Kyora, B., Kucukkalipci, I., Michel, M., Mittnik, A., Nägele, K., Novak, M., Oppenheimer, J., Patterson, N., Pfrengle, S., Sirak, K., Stewardson, K., Vai, S., Alexandrov, S., Alt, K. W., Andreescu, R., Antonović, D., Ash, A., Atanassova, N., Bacvarov, K., Gusztįv, M. B., Bocherens, H., Bolus, M., Boroneanž, A., Boyadzhiev, Y., Budnik, A., Burmaz, J., Chohadzhiev, S., Conard, N. J., Cottiaux, R., Čuka, M., Cupillard, C., Drucker, D. G., Elenski, N., Francken, M., Galabova, B., Ganetovski, G., Gely, B., Hajdu, T., Handzhyiska, V., Harvati, K., Higham, T., Iliev, S., Janković, I., Karavanić, I., Kennett, D. J., Komšo, D., Kozak, A., Labuda, D., Lari, M., Lazar, C., Leppek, M., Leshtakov, K., Vetro, D. L., Los, D., Lozanov, I., Malina, M., Martini, F., McSweeney, K., Meller, H., Menšušić, M., Mirea, P., Moiseyev, V., Petrova, V., Price, T. D., Simalcsik, A., Sineo, L., Šlaus, M., Slavchev, V., Stanev, P., Starović, A., Szeniczey, T., Talamo, S., Teschler-Nicola, M., Thevenet, C., Valchev, I., Valentin, F., Vasilyev, S., Veljanovska, F., Venelinova, S., Veselovskaya, E., Viola, B., Virag, C., Zaninović, J., Zäuner, S., Stockhammer, P. W., Catalano, G., Krauß, R., Caramelli, D., Zarina, G., Gaydarska, B., Lillie, M.,. Nikitin, A. G., Potekhina, I., Papathanasiou, A., Borić, D., Bonsall, C., Krause, J., Pinhasi, R., Reich, D. (2017). The genomic history of Southeastern Europe. bioRxiv preprint May 9, 2017; doi: http://dx.doi.org/10.1101/135616.

Merryweather-Clarke, A. T., Pointon, J. J., Shearman, J. D., Robson, K. J. (1997). Global prevalence of putative haemochromatosis mutations. J. Med. Genet., 34, 275-278.
Mielnik-Sukorska, M., Daca, P., Wožniak, M., Malyarchuk, B.A., Bednarek, J., Dobosz, T., Grzybowski, T. (2013). Genetic data from Y chromosome STR and SNP loci in Ukrainian population. Forensic Sci. Int. Gen., 7, 200-203.

Milman, N., Pedersen, P., Ovesen, L., Melsen, G. V., Fenger, K. (2004). Frequency of the $\mathrm{C} 282 \mathrm{Y}$ and H63D mutations of the hemochromatosis gene (HFE) in 2501 ethnic Danes. Ann. Hematol., 83, 654-657.

Mittnik, A., Wang, C.-C., Pfrengle, S., Daubaras, M., Zarina, G., Hallgren, F., Allmäe, R., Khartanovich, V., Moiseyev, V., Furtwängler, A., Valtueńa, A. A., Feldman, M., Economou, C., Oinonen, M., Vasks, A., Törv, M., Balanovsky, O., Reich, D., Jankauskas, R., Haak, W., Schiffels, S., Krause, J. (2017). The genetic history of Northern Europe. bioRxiv preprint Mar.3, 2017; doi: http://dx.doi.org/10.1101/113241.

Mittnik, A., Wang, C.-C., Pfrengle, S., Daubaras, M., Zarina, G., Hallgren, F., Allmäe, R., Khartanovich, V., Moiseyev, V., Törv, M., Furtwängler, A., Valtueńa, A. A., Feldman, M., Economou, C., Oinonen, M., Vasks, A., Balanovska, E., Reich, D., Jankauskas, R., Haak, W., Schiffels, S., Krause, J. (2017b). The genetic prehistory of the Baltic Sea region (in press).

Mosse, N. I., Mosse, K. A. (2005). Prenatal diagnosis of cystic fibrosis in Belarus. Proc. Belarusian Acad. Sci., Medical Sciences, No. 2, 112-117.

Nelis, M., Esko, T., Mägi, R., Zimprich, F., Toncheva, D., Karachanak, S., Piskįčkovị, T., Balaščik, I., Peltonen, L., Jakkula, E., Rehnström, K., Lathrop, M., Heath, S., Galan, P., Schreiber, S., Meitinger, T., Pfeufer, A., Wichmann, H.-E., Melegh, B., Polgįr, N., Toniolo, D., Gasparini, P., D’Adamo, P., Klovins, J., Nikitina-Zake, L., Kučinskas, V., Kasnauskienè, J., Lubinski, J., Debniak, T., Limborska, S., Khrunin, A., Estivill, X., Rabionet, R., Marsal, S., Juliá, A., Antonarakis, S. E., Deutsch, S., Borel, C., Attar, H., Gagnebin, M., Macek, M., Krawczak, M., Remm, M., Metspalu, A. (2009). Genetic structure of Europeans: a view from the North-East. PloS One, 4 (5), e5472.

Novotna, P., Blažek, V. (2007). Glottochronology and its application to the Balto-Slavic languages. Baltistica, 42, 323-346.

Pagani, L., Lawson, D. J., Jagoda, E., Mörseburg, A., Eriksson, A., Mitt, M., Clemente, F., Hudjashov, G., DeGiorgio, M., Saag, L., Wall, J. D., Cardona, A., Mägi, R.,Wilson Sayres, M. A., Kaewert, S., Inchley, C., Scheib, C. L., Järve, M., Karmin, M., Jacobs, G. S., Antao, T., Iliescu, F. M., Kushniarevich, A., Ayub, Q.,Tyler-Smith, C., Xue, Y., Yunusbayev, B., Tambets, K., Mallick, C. B., Saag, L., Pocheshkhova, E., Andriadze, G., Muller, C.,. Westaway, M. C., Lambert, D. M., Zoraqi, G., Turdikulova, S., Dalimova, D., Sabitov, Z., Sultana, G. N. N., Lachance, J., Tishkoff, S., Momynaliev, K., Isakova, J., Damba, L. D., Gubina, M., Nymadawa, P., Evseeva, I., Atramentova, L., Utevska, O., Ricaut, F.-X., Brucato, N., Sudoyo, H., Letellier, T., Cox, M. P., Barashkov, N. A., Škaro, V., Mulahasanovic', L., Primorac, D., Sahakyan, H., Mormin, M., Eichstaedt, C. A., Lichman, D. V., Abdullah, S., Chaubey, G., Wee, J. T. S., Mihailov, E., Karunas, A., Litvinov, S., Khusainova , R., Ekomasova, N., Akhmetova, V., Khidiyatova, I., Marjanović, D., Yepiskoposyan, L., Behar, D. M., Balanovska, E., Metspalu, A., Derenko, M., Malyarchuk, B., Voevoda, M., Fedorova, S. A., Osipova, L. P., Lahr, M. M., Gerbault, P., Leavesley, M., Migliano, A. B., Petraglia, M., Balanovsky, O., Khusnutdinova, E. K., Metspalu, E., Thomas, M. G., Manica, A., Nielsen, R., Villems, R., Willerslev, E., Kivisild, T., Metspalu, M. (2016). Genomic analyses inform on migration events during the peopling of Eurasia. $\mathrm{Na}$ ture, 538, 238-242.

Pampukha, V. M., Rozumenko, V. D., Cherchenko, A. P., Livshits, L. A. (2003). Analysis of C282Y and H63D mutations of the hereditary haemochromatosis gene HFE among the Ukrainian population and patients with brain glial tumor. Biopolymers Cell, 19, 536-540.

Pliss, L. (2007). Mitochondrial DNA (mtDNA) variation and its role in ethnogenesis of Latvians. Doctoral dissertation, University of Latvia.

Pliss, L., Tambets, K., Loogväli, E.-L., Pronina, N., Lazdins, M., Krumina, A., Baumanis, V., Villems, R. (2006). Mitochondrial DNA portrait of Latvians: Towards the understanding of the genetic structure of Baltic-speaking populations. Ann. Hum. Genet., 70, 439-458. 
Pliss, L., Timša, L., Rootsi, S., Tambets, K., Pelnena, I., Zole, E., Puzuka, A., Sabule, A., Rozane, S., Lace, B., Kucinskas, V., Krumina, A., Ranka, R., Baumanis, V. (2015). Y-chromosomal lineages of Latvians in the context of the genetic variation of the Eastern-Baltic region. Ann. Hum. Genet., 79, $418-430$.

Posth, C., Renaud, G., Mittnik, A., Drucker, D. G., Rougier, H., Cupillard, C., Valentin, F., Thevenet, C., Furtwängler, A., Wißing, C., Francken, M., Malina, M., Bolus, M., Lari, M., Gigli, E., Capecchi, G., Crevecoeur, I., Beauval, C., Flas, D., Germonpré, M., van der Plicht, J., Cottiaux, R., Gély, B., Ronchitelli, A., Wehrberger, K., Grigorescu, D., Svoboda, J., Semal, P., Caramelli,D., Bocherens, H., Harvati, K., Conard, N. J., Haak, W., Powell, A., Krause, J. (2016). Pleistocene mitochondrial genomes suggest a single major dispersal of non-Africans and a Late Glacial population turnover in Europe. Curr. Biol., 26, 827-833.

Prīmanis, J. (1937). Latviešu antropologiskais raksturojums [Anthropological Characterization of the Latvians]. Valtera un Rapas akc. sab.apgāds, Rìga. 40 lpp. (in Latvian)

Pronina, N., Lugovska, R. (2011). Association between minihaplotypes and mutations at the phenylalanine hydroxylase locus in Latvian phenylketonuria patients. Proceed. Latv. Acad. Sci., Section B, 65 (3/4), 73-79.

Purina, G., Lugovska, R., Sokolova, L. (1995). Medical genetical service in Latvia: Developmental trends. Proceed. Latv. Acad. Sci., No. 5/6, 5-8.

Radiņš, A. (2012). Arheoloğisks ceļvedis latviešu un Latvijas vēsturē [Archaeological Guide in the History of Latvians and Latvia]. Apgāds Neputns, Rīga. 415 lpp. (in Latvian).

Rebala, K., Martinez-Cruz, B., Tönjes, A., Kovacs, P., Stumvoll, M., Lindner, I., Büttner, A., Wichmann, H.-E., Siváková, D., Soták, M., Quintana-Murci, L., Szczerkowska, Z., Comas, D., Genographic Consortium (2012). Contemporary paternal genetic landscape of Polish and German populations: From early medieval Slavic expansion to post-World War II resettlements. Eur. J. Hum. Genet., 21, 415-422.

Richards, M., Corte-Real, H., Forster, P., Macaulay, V., Wilkinson-Herbots, H., Demaine, A., Papiha, S., Hedges, R., Bandelt, H.-J., Sykes, B. (1996). Paleolithic and neolithic lineages in the European mitochondrial gene pool. Amer. J. Hum. Genet., 59, 185-203.

Rimantiene, R. (1996). Akmens amžius Lietuvoje [The Stone Age in Lithuania]. 2nd edn. Vilnius, Žiburio leidykla (in Lithuanian).

Rosser, Z. H., Zerjal, T., Hurles, M. E., Adojaan, M., Alavantic, D., Amorim, A., Amos, W., Armenteros, M., Arroyo, E., Barbujani, G., Beckman, G., Beckman, L., Bertranpetit, J., Bosch, E., Bradley, D. G., Brede, G., Cooper, G., Corte-Real, H. B., de Knijff, P., Decorte, R., Dubrova, Y. E., Evgrafov, O., Gilissen, A., Glisic, S., Golge, M., Hill, E. W., Jeziorowska, A., Kalaydjieva, L., Kayser, M., Kivisild, T., Kravchenko, S. A., Krumina, A., Kučinskas, V., Lavinha, J., Livshits, L. A., Malaspina, P., Maria, S., McElreavey, K., Meitinger, T. A., Mikelsaar, A. V., Mitchell, R. J., Nafa, K., Nicholson, J., Norby, S., Pandya, A., Parik, J., Patsalis, P. C., Pereira, L., Peterlin, B., Pielberg, G., Prata, M. J., Previderé, C., Roewer, L., Rootsi, S., Rubinsztein, D. C., Saillard, J., Santos, F. R., Stefanescu, G., Sykes, B. C., Tolun, A., Villems, R., Tyler-Smith, C., Jobling, M. A. (2000). Y-chromosomal diversity in Europe is clinal and influenced primarily by geography, rather than by language. Amer. J. Hum. Genet., 67, 1526-1543.

Saag, L., Varul, L., Scheib, C. L., Stenderup, J., Allentoft, M. E., Saag, L., Pagani, L., Reidla, M., Tambets, K., Metspalu, E., Kriiska, A., Willerslev, E., Kivisild, T., Metspalu, M. (2017). Extensive farming in Estonia started through a sex-biased migration from the Steppe. Curr. Biol., 27, 2185-2193.

Sajantila, A., Lahermo, P., Anttinen, T., Lukka, M., Sistonen, P., Savontaus, M. L., Aula, P., Beckman, L., Tranebjaerg, L., Gedde-Dahl, T., Issel-Tarver, L., DiRienzo, A., Paabo, S. (1995). Genes and languages in Europe: An analysis of mitochondrial lineages. Genome Res., 5, 42-52.

Scrimshaw, N., Murray, E. (1988). The acceptability of milk and milk products in populations with a high prevalence of lactose intolerance. Amer. J. Clin. Nutr., 48, 1079-1159.
Sedovs V. (2004). Balti senatnē [Balts in Ancient Times]. 2nd ed. Latvijas Vēstures Institūta apgāds, Rīga. 165 lpp. (in Latvian).

Seixas, S., Garcia, O., Trovoada, M. J., Santos, M. T., Amorim, A., Rosha, J. (2001). Patterns of haplotype diversity within the serpin gene cluster at 14q32.1: Insights into the natural history of the alpha 1-antitrypsin polymorphism. Hum. Genet., 108, 20-30.

Sistonen, P., Virtaranta-Knowles, K., Denisova, R., Kucinskas, V., Ambrasiene, D., Beckman, L. (1999). The LWb blood group as a marker of prehistoric Baltic migrations and admixture. Hum. Hered., 49, 154-158.

Sivitskaya, L., Danilenko, N., Zabarouskaya, Z., Davydenko, O. (2013). $H F E$ gene mutation associated with the severity of gestational diabetes mellitus in Belarusian women. Open J. Endocr. Metab. Dis., 3, 13-17.

Skoglund, P., Malmström, H., Raghavan, M., Storå, J., Hall, P., Willerslev, E., Gilbert, M. T., Götherström, A., Jakobsson, M. (2012). Origins and genetic legacy of Neolithic farmers and hunter-gatherers in Europe. Science, 336, 466-469.

Slatkin, M. (2001). Simulating genealogies of selected alleles in a population of variable size. Genet. Res., 78, 49-57.

Smith, G. D., Lawlor, D. A., Timpson, N. J., Baban, J., Kiessling, M., Day, I. N. M., Ebrahim, S. (2009). Lactase persistence-related genetic variant: Population substructure and health outcomes. Eur. J. Hum. Gen., 17, 357-367.

Srivastava, K., Almarry, N. S., Flegel, W. A. (2014). Genetic variation of the whole ICAM4 gene in Caucasians and African Americans. Transfusion, 54, 2315-2324.

Stepanova, A. A., Krasovsky, S. A., Polyakov, A. V. (2016). Reliability of the search for 19 common mutations in the CFTR gene in Russian cystic fibrosis patients and the calculated frequency of the disease in Russian Federation. Rus. J. Genet., 52, 204--213.

Stephens, J. C., Reich, D. E., Goldstein, D. B., Shin, H. D., Smith, M. W., Carrington, M., Winkler, C., Huttley, G., Allikmets, R., Schriml, L., Gerrard, B., Malasky, M., Ramos, M. D., Morlot, S., Tzetis, M., Oddoux, C., Giovine, F. S., Nasioulas, G., Chandler, D., Aseev, M., Hanson, M., Kalaydjieva, L., Glavac, D., Gasparini, P., Kanavakis, E., Claustres, M., Kambouris, M., Ostrer, H., Duff, G., Baranov, V., Sibul, H., Metspalu, A., Goldman, D., Martin, N., Duffy, D., Schmidtke, J., Estivill, X., O`Brien, S. J., Dean, M. (1998). Dating the origin of the CCR5-Delta 32 AIDS-resistance allele by the coalescence of haplotypes. Amer. J. Hum. Genet., 62, 1507-1515.

Stumpf, M. P.,Wilkinson-Herbots, H. M. (2004). Allelic histories: Positive selection on a HIV-resistance allele. Trends Ecol. Evol., 19, 166-168.

Tambets, K., Rootsi, S., Kivisild, T., Help, H., Serk, P., Loogväli, E.-L., Tolk, H.-V., Reidla, M., Metspalu, E., Pliss, L., Balanovsky, O., Pshenichnov, A., Balanovska, E., Gubina, M., Zhadanov, S., Osipova, L., Damba, L., Voevoda, M., Kutuev, I., Bermisheva, M., Khusnutdinova, E., Gusar, V., Grechanina, E., Parik, J., Pennarun, E., Richard, C., Chaventre, A., Moisan, J.-P., Barać, L., Peričić, M., Rudan, P., Terzić, R., Mikerezi, I., Krumina, A., Baumanis, V., Koziel, S., Rickards, O., De Stefano, G. F., Anagnou, N., Pappa, K. I., Michalodimitrakis, E., Ferįk, V., Füredi, S., Komel, R., Beckman, L., Villems, R. (2004). The Western and Eastern roots of the Saami - the story of genetic "outliers" told by mitochondrial DNA and Y chromosomes. Amer. J. Hum. Genet., 74, 661-682.

Tighe, O., Dunican, D., O`Neill, C., Bertorelle, G., Beattie, D., Graham, C., Zschocke, J., Cali, F., Romano, V., Hrabincova, E., Kozak, L., Nechyporenko, M., Livshits, L., Guldberg, P., Jurkowska, M., Zekanowski, C., Perez, B., Desviat, L. R., Ugarte, M., Kucinskas, V., Knappskog, P., Treacy, E., Naughten, E., Tyfield, L., Byck, S., Scriver, C. R., Mayne, P. D., Croke, D. T. (2003). Genetic diversity within the R408W Phenylketonuria mutation lineages in Europe. Hum. Mutat., 21, 387-393.

Torroni, A., Achilli, A., Macalay, V., Richards, M., Bandelt, H. J. Harvesting the fruit of the human mtDNA tree. Trends Genet., 22 (6), 339-345.

Underhill, P. A., Myres, N. M., Rootsi, S., Metspalu, M., Zhivotovsky, L. A., King, R. J., Lin, A. A., Chow, C. E., Semino, O., Battaglia, V., Kutuev, I., 
Järve, M., Chaubey, G., Ayub, Q., Mohyuddin, A., Mehdi, S. Q., Sengupta, S., Rogaev, E. I., Khusnutdinova, E. K., Pshenichnov, A., Balanovsky, O., Balanovska, E., Jeran, N., Augustin, D. H., Baldovic, M., Herrera, R. J., Thangaraj, K., Singh, V., Singh, L., Majumder, P., Rudan, P., Primorac, D., Villems, R., Kivisild, T. (2010). Separating the post-Glacial coancestry of European and Asian Y chromosomes within haplogroup R1a. Eur. J. Hum. Genet., 18, 479-484.

Underhill, P. A., Poznik, G. D., Rootsi, S., Järve, M., Lin, A. A., Wang, J., Passarelli, B., Kanbar, J., Myres, N. M., King, R. J., di Cristofaro, J., Sahakyan, H., Behar, D. M., Kushniarevich, A., Šarac, J., Šaric, T., Rudan, P., Pathak, A. K., Chaubey, G., Grugni, V., Semino, O., Yepiskoposyan, L., Bahmanimehr, A., Farjadian, S., Balanovsky, O., Khusnutdinova, E. K., Herrera, R. J., Chiaroni, J., Bustamante, C. D., Quake, S. R., Kivisild,T., Villems, R. (2015). The phylogenetic and geographic structure of Y-chromosome haplogroup R1a. Eur. J. Hum. Genet., 23, 124-131.

Vasks, A., Vaska, B., Gravere, R. (1997). Latvijas aizvēsture [The Prehistory of Latvia]. Zvaigzne ABC, Rīga, 223 lpp. (in Latvian).

Voicu, P. M., Cojocariu, C., Petrescu-Danila, E., Covic, M., Stanciu, C., Rusu, M. (2009). Prevalence of HFE (hemachromatosis) gene mutations C282Y and H63D in Romanian population. Blood Cells Mol. Dis., 42, 14-15.

Vuorisalo, T., Arjamaa, O., Vasemägi, A., Taavitsainen, J.-P., Tourunen, A., Saloniemi, I. (2012). High lactose tolerance in North Europeans: A result of migration, not in situ milk consumption. Persp. Biol. Med., 55, 163-174.
Williams, R. A., Mamotte, C. D. S., Burnett, J. R. (2008). Phenylketonuria: An inborn error of phenylalanine metabolism. Clin. Biochem., 29, 31-41.

World Health Organization. The molecular genetic epidemiology of cystic fibrosis. Available at:

www.who.int/genomics/publications/en/HGN_WB_04.02_report.pdf

Zagorska, I. (2012). Senie ziemeļbriežu mednieki Latvijā [The Ancient Reindeer Hunters in Latvia]. Zinātne, Rīga. 206 lpp. (in Latvian).

Zerjal, T., Beckman, L., Beckman, G., Mikelsaar, A.-V., Krumina, A., Kučinskas, V., Hurles, M. E., Tyler-Smith, C. (2001). Geographical, linguistic, and cultural influences on genetic diversity: Y-chromosomal distribution in Northern European populations. Mol. Biol. Evol., 18, 1077-1087.

\section{ONLINE RESOURCES}

1000 genomes browser: phase3browser.1000genomes.org (accessed 15.12.2017).

dbSNP database: https://www.ncbi.nlm.nih.gov/snp/ (accessed 15.12.2017).

Ensembl database: https://www.ensembl.org (accessed 15.12.2017).

ExAc database: exac.broadinstitute.org/ (accessed 15.12.2017).

Online Mendelian Inheritance of man: https://www.omim.org (accessed 15.12.2017).

Received 24 July 2017

Accepted in the final form 2 January 2018

\section{LATVIEŠU POPULĀCIJU GENĒTIKA SAISTĪBĀ AR ZIEMELALUSTRUMEIROPAS ETNISKO GRUPU SAJAUKUMU}

Pārskata rakstā ir apkopoti dati par populāciju genētiskajiem pētījumiem latviešiem — vienai no divām mūsdienās baltu valodās runājošajām populācijām. Rakstā sniegta informācija par genoma viena nukleotīda polimorfismu plašas analīzes datiem, dots salīdzinājums ar apkārtējo populāciju datiem, izmantojot arī klasisko autosomālo marķieru, mitohondriālās DNS (mtDNS), Y hromosomas nerekombinējošās daḷas, kā arī no seno kaulu paraugiem izdalītās DNS pētījumu rezultātus. Latviešiem ir vērojama Rietumeiropas un Austrumeiropas populācijām raksturīgo ǵenētisko pazīmju kombinācija, atklājot tikai nelielas atškirības starp mūsdienu Latvijas reğioniem. Baltu izcelsmes alēles LWb (ICAM4 gēnā) un gēna SERPINAl alēles PIZ pētījumi norāda uz vērā ņemamu baltu géenētiskā materiāla klātbūtni kaimiņu somugru un slāvu populācijās. Lai gan mtDNS pētījumi liecina, ka latvieši ğenētiski ir līdzīgi lielākajai daḷai eiropiešu populāciju, Y hromosomas analīzes dati norāda, ka vislielākā līdzība latviešiem ir vērojama ar Ziemel̦eiropas un Austrumeiropas kaimiņu populācijām - lietuviešiem, igauņiem un austrumslāviem. Senās DNS analīze no Agrā un Vidējā Neolīta mednieku un vācēju kaulu paraugiem, kas iegūti mūsdienu Latvijas un Lietuvas teritorijā, neatklāj Centrāleiropas zemkopju genomu piejaukuma pēdas. 